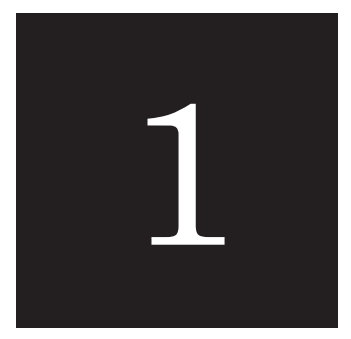

\title{
LA ADJUDICACIÓN JURÍDICA UNA MIRADA AL JUEZ GRIEGO, AL MEDIEVAL Y AL JUEZ ACTUAL COMO ATENEA
}

Siendo Oliver Wendell Holmes magistrado del Tribunal Supremo, en una ocasión de camino al Tribunal llevó a un joven: Learneld Hand en su carruaje. Al llegar a su destino, Hand se bajó, saludó en dirección al carruaje que se alejaba y dijo alegremente: “¡Haga justicia, magistrado!”. Holmes paró el carruaje, hizo que el conductor girara, se dirigió hacia el asombrado Hand y, sacando la cabeza por la ventana, le dijo: “!Ese no es mi trabajo!”. A continuación el carruaje dio vuelta y se marchó, llevándose a Holmes a su trabajo, supuestamente consistente en no hacer justicia (Dworkin, 2007, p. 11).

\section{Introducción}

El derecho en clave posmoderna se ve enfrentado, como las demás disciplinas, al examen histórico, del lugar del Juez, de su acción práctica de adjudicación, que es afectada por las vicisitudes propias de su tiempo, y que recoge en últimas el espíritu y los signos de los tiempos. Cada momento y, en especial para esta investigación, el mundo griego y el medieval dan cuenta de las aspiraciones culturales y sociales acerca de la justicia, la paz y el orden social al que está unido de manera fuerte el juez en sus decisiones y que afectan a los ciudadanos de todos los tiempos. El juez del siglo XXI en sus fallos comparte de manera esencial los temas y problemas del juez griego y medieval, como quiera que los hombres en conjunto están abatidos por las realidades humanas que 
trascienden la temporalidad, como los vicios y las inequidades en tanto formas de la injusticia. Por otro lado, los togados, como ciudadanos con una dignidad especial, están sujetos a la mirada escrutadora desde la ética y la moral pública ciudadana de su acción, y esperan que sus fallos estén de alguna manera en sintonía con los consensos y los ideales de lo justo, lo bueno y deseable para todos. Otro análisis del que no es posible sustraer la adjudicación es el analítico y hermenéutico, que en el caso griego y medieval ha de hacerse desde cierto horizonte de unidad colectiva, pero que en el caso de la posmodernidad el horizonte es fragmentario y provisional, que bien pueden definirse en su carácter fuerte como de consumidores. La sociedad de consumidores es creativa e instaura nuevos sujetos:

La característica más prominente de la sociedad de consumidores -por cuidadosamente que haya sido escondida o encubierta- es su capacidad de transformar a los consumidores en productos consumibles, o más bien de disolverlos en un mar de productos (...) 'y por lo tanto las cosas mismas, son experimentadas como insustanciales” y parecen "uniformemente planas y grises', mientras 'flotan con igual peso específico en el flujo de un constante río de dinero' (Bauman, 2011, p. 26).

Estos conjuntos humanos que en la primera mitad del siglo XX renovaron el espíritu de la razón, que estaba anegada por la razón instrumental, al instaurar la dignidad humana y los derechos fundamentales como pivotes del orden jurídico. Se ven hondamente cuestionados con los cambios que emergen en la década del 70 del siglo XX, porque ante las fuertes expresiones de la realidad posmoderna con otros simbolismos y representaciones se construyen otros hombres, entre los que está el hombre del consumo, que por antonomasia termina como opción antropogénica. Las comunidades consumidoras, como construcciones saturadas de imágenes viven el exceso como entorno vital "hoy es exceso "Y como ya no somos capaces de afrontar el dominio simbólico de la ausencia, estamos sumidos en la ilusión contraria, la ilusión, 
desencantada, de la proliferación de las pantallas y las imágenes” (Baudrillard, 2009, p. 15) no es posible el consumo sin la presencia permanente, además de esencial y necesaria de las tecnologías, no es posible pensar el hoy y el desarrollo cotidiano sin estas, porque definen los roles y el lugar del individuo en el conjunto. "Acerca del rol definitivo de la tecnología. "En la era actual, la mayoría tiene la cabeza enterrada, pero en una marca de desktops, laptops, celulares y dispositivos que caben en la palma de la mano” (Bauman, 2011, p. 33), vacíos y desintegración de la realidad han dispersado el sentido o los sentidos, que eran referentes de la vida en conjunto. Realidad social que se antoja virtual, como categoría en su sentido fuerte más allá de la mera idea de que es irreal, o que se trata de algo extraño o exótico, que no está en las rutas de lo aquí y lo ahora "la imagen ya no puede imaginar lo real, ya que ella misma lo es. Ya no puede soñarlo, ya que ella es su realidad virtual (...) Sólo la tecnología sigue tal vez uniendo los fragmentos dispersos de lo real” (Baudrillard, 2009, p. 15) compleja, expuesta, desigual, saturada y problemática, que es justo a la que se enfrenta el juez en la aplicación del derecho al caso concreto, es decir, en la práctica de la adjudicación. La sociedad presente se evidencia alejada de los universos griegos y medievales, para los cuales los referentes generaban confianza, pues estaban más claros y quizá con pocas sospechas, por el contrario, hoy prevalece más bien una clara decepción "la decepción forma parte de la condición humana, es preciso observar que la civilización moderna, individualista y democrática, le ha dado un peso y un relieve excepcionales, un área psicológica y social sin precedentes históricos” (Lipovetsky, 2008, p. 20) de los valores tradicionales, desordenada, con principios y referentes difusos, que no cohesionan y anudan el tejido social, sino que los relativizan al presente y al consumo, oscurece el postulado de la justicia, como fundante del orden social, y difícilmente puede hacer acuerdos mínimos y consensos de legitimidad "queda completamente abierta de nuevo tras la retirada del Estado de la función sobre la que se fundamentaron sus pretensiones de legitimidad (...) puede construirse un nuevo consenso de ciudadanía ('patriotismo constitucional', por emplear la 
expresión de Jürgen Habermas)" (Bauman, 2010, p. 26). Además, lo social se manifiesta como desconfianza por la ciudadanía, convivencia solidaria y fraternidad, que de alguna manera estaban presentes en los ideales griegos y medievales. La sociedad del hoy vive otra forma de globalización, así como la vivieron los griegos y medievales, que ha logrado expandir la desconfianza "erosiona los postulados básicos del Estado, el derecho y la justicia (...) las normas no son como deberían ser (o como creemos que podrían ser), estamos inclinados a sospechar (...) la existencia de una falta censurable de buena voluntad" (Bauman, 2010, p. 82), el nihilismo y la sospecha en que el Estado, el derecho y los jueces son incapaces de proteger a la comunidad, en permanente alarma. Se percibe el mundo social desde cierta desubtancialización porque solo queda espacio para lo accidental, en algunos momentos, incluso, se trata de coyunturas intensas que pasan por esenciales y definitivas; los postulados de la democracia del mismo Estado Social de Derecho, quedan expuestos de manera fuerte pero con fecha de expiración "la fase de afirmación gloriosa y heroica de las democracias (...) (la nación, la igualdad, el socialismo) con los discursos jerárquicos destronados, entramos en la era democrática posmoderna que se identifica con la desubstancialización humorística de los principales criterios sociales” (Lipovetsky, 2006, p. 162). Al desentronizar aquello que es esencial, el horizonte de reflexión y de sentido muta quizá hacia otras arquitecturas del orden social, político y de la cultura misma. Queda el reto por reactualizar y repensar desde categorías del hoy, y desde una epistemología plural, de frontera la acción práctica de la razón jurídica que supere los afanes del momento y las encrucijadas de la sin justicia, la sin ética y la relativización de los principios a las presiones posmodernas. Razón práctica jurídica o racionalidad legal desde un paradigma abierto, diverso, es el que demanda las decisiones judiciales, y retan un nuevo rol del juez, en estos contextos sociales difíciles y paradigmáticos: 
La "epopeya" de la purificación de la teoría ya cumplió su cometido, ahora hay que emprender otra tarea de signo contrario, esto es, despurificar la teoría para construir, en la intersección con otros saberes, un paradigma cognitivo de nuevo tipo, capaz de dar cuenta del papel del derecho en el marco de la sociedad compleja del siglo XXI (Cárcova, 2009, p. 3).

El juez, sin que sea la figura determinante en la cultura sí es polémica por el impacto social, más aún cuando se debate en esta época, si se está ante una nueva forma de poder, en la versión del gobierno de los jueces. El juez como figura de poder que relee y reconduce el mismo desde los signos de los tiempos, y los quereres colectivos, no se puede sustraer a las formas de poder, que son el carácter de los hombres: "toda construcción teórica acerca del derecho mantiene siempre vínculos insoslayables con la problemática general. Es decir, con la problemática de la circulación de la ideología, de la construcción del discurso político, de la legitimación y reconducción de las estructuras de poder” (Cárcova, 2009, p. 97). El juez del siglo XXI, como parte de la cultura jurídica, y compartiendo la tradición que se ha creado desde la cosmogonía y la filosofía griega y medieval, pervive en él, aspectos y dimensiones que como un río portentoso, pareciera por las formas rituales que asume en el desempeño de su labor hoy, que aún están presentes, mucho más cuando cada vez hay un mayor reclamo, de manera paradójica y paradigmática por parte de la comunidad de intérpretes, por el valor de la ética, la moral, la interpretación y la hermenéutica en la aplicación del derecho, como práctica social discursiva. Es fuerte la carga práctica del derecho, porque la adjudicación en el mundo griego, medieval y en el de hoy, es una acción concreta como fenómeno humano, con impacto colectivo, por lo que han de aplicar lo debido en cada caso por los jueces, pero práctica que ha de ser pensada, teorizada y criticada desde las tendencias epocales: "La ciencia del derecho, tal como se cultiva en la actualidad, es, ante todo, una disciplina práctica porque su pregunta central es: ¿qué es lo debido en los casos reales o imaginarios?” (Alexy, 2008, p. 16). 


\section{La adjudicación, como virtud práctica de la justicia en los jueces griegos}

Una de las primeras tendencias del lugar del juez, y su incidencia en la construcción del tejido social se encuentra en el universo griego, en el mundo teológico que compartían como proyecto político, moral, jurídico, cuya figura encarnaba el juez supremo, el dios Zeus, pues él era el encargado de examinar la vida de los hombres, realizaba una valoración, en la que contaba con un tribunal colegiado, con funciones específicas en esta labor de juzgar, juzgaba las acciones de todas las almas, y como jefe de las tres parcas, tenía señorío sobre todos. Las parcas tenían labores específicas en el juicio definitivo, la vida del hombre pendía de un hilo, un hilo tejido con su propia vida, pero como hilo también era cercenado por la voluntad de los dioses: Cloto era la hilandera, su tarea era tejer las hebras de la vida, Láquesis media el hilo de la vida, ella sopesaba la existencia, el alma virtuosa o viciosa. Y Átropo tenía la misión de segar el hilo, pues ella poseía las tijeras para cortar el alma, para acabar la vida. Zeus mandaba sobre ellas, en sus manos de juez, estaba el destino del hilo de la vida y así decidía si se debía cortar o no, su labor era interpretativa, relativa a la vida moral y virtuosa de los hombres, a las acciones de justicia, como el fin supremo a conseguir por cada república personal:

...valora las vidas de los hombres e informa a las Moiras sobre sus conclusiones, cambia de opinión e interviene para salvar a quien le place cuando el hilo de la vida, hilado en el huso de Cloto y medido con la vara de Láquesis, está a punto de ser cortado por las tijeras de Átropo (Graves, 2011, p. 68).

Era juez supremo y soberano "Zeus se llamaba a sí mismo "Jefe de las Parcas” cuando asumía la suprema soberanía y se adjudicaba la prerrogativa de evaluar la vida del hombre” (Graves, 2011, p. 69) y como tal enjuiciaba la vida de los mortales y sin duda de la Polis, porque ciudadano y polis, eran uno solo. Pero el juzgamiento también acaecía en otro escenario en el mundo subterráneo o tártaro, regentado por el 
igualmente poderoso Hades, juez supremo que también compartía el juicio del alma humana, junto a otros tres dioses, quienes cumplían esta labor de juzgar. Estos jueces, todos los días sometían a juicio a las ánimas que descendían hasta allí, ellos eran Minos, Radamantis y Éaco; cada uno juzgaba a un grupo de ánimas, así Radamantis debía sentenciar a los asiáticos, Éaco a los europeos y llama la atención que los casos difíciles de juzgar eran reservados a la potestad de Minos "las ánimas recién llegadas son juzgadas diariamente por Minos, Radamantis y Éaco en el punto de confluencia de tres caminos. Radamantis juzga a los asiáticos y Éaco a los europeos; pero ambos dirigen los casos difíciles a Minos” (Graves, 2011, p. 178). Los criterios para juzgar las almas de los hombres eran la virtud y la maldad, si el alma no es virtuosa ni mala, el fallo era ir a Asfódelos, si el alma era mala, su lugar era el castigo en el Tártaro; si el alma es virtuosa su lugar era los Jardines del Elíseo, regido por Crono, este era un lugar apacible y dichoso, incluso gracias a la virtud de los hombres, estos pueden volver a vivir en la Tierra si es su voluntad, ellos los virtuosos podían reencarnar gracias a su bondad:

...es una tierra feliz donde el día es eterno, sin frío ni nieve, en la cual nunca cesan los juegos, la música y las fiestas, y donde sus habitantes pueden decidir renacer en la tierra siempre que les plazca. Cerca están las Islas de los Bienaventurados, reservadas para aquellos que han encarnado tres veces y tres veces han merecido el Elíseo (Graves, 2011, p. 178).

En el universo espiritual griego, también el quehacer de adjudicar en el mundo de los hombres, se consagra a dos diosas Diké y Themis, traídas y asumidas de la herencia religiosa Jónica, incorporadas como las diosas tutelares de los jueces en sus decisiones y cuya pretensión y destino es el bien más preciado para todo griego, el cuidado del alma que se traduce como la vida virtuosa: Themis, como diosa “('Temis' y 'Teseo', a partir de tithenai, que significa 'disponer' u 'ordenar') (Graves, 2011, p. 71). Ella representa y es la ley, la autoridad del derecho, la legalidad y la validez "Themis se refiere más bien a la autoridad del derecho, a su legalidad y validez” (Jaeger, 1994, p. 107). La diosa Diké está 
más unida al proceso, se provee Diké y se apodera Diké, Diké es dar lo debido “diké no es etimológicamente claro. Procede del lenguaje procesal y no es menos antiguo que Themis (...) partes contendientes que "dan y toman diké". Se comprendía así en una misma palabra la decisión y cumplimiento de la pena” (Jaeger, 1994, p. 106). Estas diosas representan la doble dimensión que se concreta al momento de juzgar, porque al momento de aplicación al caso concreto, ella interviene en el fallo y se ha de acatar la pena. Las partes son intervenidas por Diké, la víctima toma Diké, el victimario concede Diké, porque compensa como forma y presencia de Diké. El juez confiere Diké instaurando así la adjudicación en el contexto espiritual griego, porque adelanta el proceso, el juicio y además castiga. Es igualdad, o alude al principio de compensación simétrica, porque se trata de compensar de equilibrar el desbalance que produce ofender a los dioses mediante las acciones injustas a los demás "El juez "adjudica diké” (...) dar a cada cual lo debido (...) el cumplimiento de la justicia (...) “medida” justa para la atribución del derecho y se halló en la exigencia de igualdad implícita en el concepto de la diké (Jaeger, 1994, p. 106)”.

La misión esencial del juez en Grecia era comprender e interpretar la justicia, el punto de partida de la adjudicación es su cosmovisión y pensamiento político espiritual, porque él está inscrito en los planes colectivos de marca espiritual. La democracia griega en su modelo, como participación directa de hombres libres y nobles, establecía los diversos servicios y ministerios que se debían cumplir en favor de la excelencia anímica de la polis. La función pública, y especialmente la de impartir justicia, era considerada como expresión de la razón práctica o moral, por tanto se trataba de la vida decorosa, de la vida virtuosa. La primera de las virtudes a la que estaba llamado todo ciudadano, era a la práctica de la justicia, cuya remembranza primera es la divinidad diké, de ahí que sea una fuerza arraigada en la mente y los corazones de todos. Por la condición de hombres piadosos y virtuosos, el clamar justicia se trata de ir más allá del resarcimiento concreto por la lesión recibida, se trata de restaurar la nobleza y el estatus menoscabado. 
En el escenario de la adjudicación griega emerge la figura del orador, que intervenía en el escenario de las almas en pugna, que coadyuva para que se desvelaran las acciones injustas de los hombres, del mal de hybris. El juez como orador tenía la labor de recta razón, porque contribuye con la reparación del orden perdido, de la armonía extraviada por los vicios. Impide que estas ofensas y ultrajes al alma atenten contra el proyecto de felicidad, se instituye en el conductor y cuidador del alma virtuosa. Sintetiza los ideales y aspiraciones de la areté y la paideia griegas, así como la entronización de la justicia en la vida privada y pública. En discursos de Isócrates, Sobre la Paz, Areopagítico, Recurso contra Calímaco, Contra Loquites y el Panatenaico dan cuenta de manera ostensible y evidente de esta filosofía de la justicia, como forma de la adjudicación, justifica dos pilares fundamentales de la cultura griega: la virtud $(\alpha \rho \varepsilon \tau \varepsilon)$ y la educación $(\pi \alpha 1 \delta \varepsilon 1 \alpha)$. Así mismo, inherentes a la idea de justicia que se compartía y se debía observar como ciudadano. La unión espiritual entre el individuo y la polis, hacía de la justicia un principio de existencia personal y colectiva; era el ideal perseguido por todos y por lo tanto exigido como imperativo moral y social "la justicia tiene que ser algo inherente al alma, una especie de salud espiritual del hombre de cuya esencia no puede dudarse” (Jaeger, 1994, p. 587). La democracia ateniense estaba concebida de tal manera, que todos los varones tenían acceso a la administración de justicia, a un ejercicio de esta función pública, bien en la calidad de juez, bien en la condición de demandante. Configurando de manera paradójica entre lo amplio y lo restringido el contexto de adjudicación, amplio, porque la participación se extendía a los varones ciudadanos, pero restringida, porque no estaba pensada para los que no eran ciudadanos, entre otros, las mujeres o a los extranjeros, como quiera que no gozaban de esta calidad. El lugar donde se desplegaba la función de adjudicación, era el Tribunal, este era el nervio de la Polis, porque los dioses también con su presencia vigilaban por la restauración del orden y el resarcimiento de las ofensas a dioses y hombres. La existencia de tribunales aseguraba la concreción de esta utopía democrática; el lugar de estos en la vida práctica de los atenienses, era fundamental y definitivo porque su rol estaba más allá, 
del de resolver los litigios entre las personas. Difícilmente se puede equiparar las funciones de los Tribunales en Atenas, con las funciones de los Tribunales actuales:

Era su deber, como el de cualquier otro tribunal, dar decisiones judiciales en los casos particulares, tanto civiles como criminales; pero, además, tenían poderes mucho mayores que éstos y que, con arreglo a las concepciones modernas, son claramente de naturaleza ejecutiva o legislativa y no judicial (Sabine, 2002, p. 88).

Su misión era regir y conducir el alma de todos y en últimas el alma de la ciudad estado. Así mismo, legitimaban la integridad de la vida moral privada y pública, ya que la acción moral era una sola, no estaba escindida, de ello da cuenta Isócrates en el Discurso sobre la paz, cuando demanda la exigencia de esta en las conductas públicas de sus conciudadanos. "Cuaquiera (sic) os censuraría (...) muchas y grandes casas han quedado destruidas por los aduladores y aunque odiáis a quienes emplean este sistema en los asuntos privados, no pensáis lo mismo sobre ellos cuando se trata de asuntos públicos” (Isocrátes, 1979, p. 11).

Para la polis y su súbdito, se trataba de conseguir y perseguir por todos los medios posibles la vida virtuosa, ya que esta aseguraba el bien, el $\alpha \gamma \alpha \tau \eta o v .{ }^{1}$ La adjudicación griega es ejercicio de la virtud del juez, que solo desde esta condición puede juzgar las almas de los ciudadanos ofensores de las divinidades. La vida virtuosa, enjuiciada, era entendida como unidad de las virtudes, concretadas en las acciones de bondad o justicia, llamada $\alpha \rho \varepsilon \tau \alpha$. Aretai que para Aristóteles es el Bien tanto del ciudadano griego como de la ciudad-Estado, las conquistas y el ideal de la polis, se centran básicamente en el compromiso con la acción virtuosa: "La virtud del ciudadano se refiere, pues, exclusivamente al Estado” (Aristóteles, 1999, p. 88). La virtud como realidad de la razón

1 Bien como agathón, expresión que en toda su polisemia estaba referida a la moral. 
práctica tenía un $\tau \varepsilon \lambda o \sigma:$ la felicidad como fin mayor para Aristóteles, esta solo es posible, si los hombres se esfuerzan por vivir la virtud y no alejarse de esta, pues no es posible conseguirla en bienes exteriores. Hay una exigencia para la consecución de esta "es siempre patrimonio de los corazones más puros, de las más claras inteligencias, y que se ha hecho para los hombres moderados en el amor de los bienes, no para los hombres pobres en virtudes, aunque opulentos en fortuna” (Aristóteles, 1999, p. 122).

De ahí que el individuo y el Estado podían ser felices, porque coincidían en una aspiración moral común. La felicidad en el elucidario Ateniense, conlleva una comprensión de la armonía que implica tener una conducta en orden, en sintonía con los otros, como unidad común de espíritu. El proyecto comunitario es categórico, no hay fractura entre la vida íntima y la vida de la ciudad, los habitantes estaban llamados a ser gobernantes y gobernados. La dignidad del que gobierna es concedida por la rectitud, por la moderación de la vida justa, por el estar sometido a la obediencia moral y a las virtudes. La vida privada del mundo griego estaba íntimamente asida a la vida pública, la exigencia moral del ciudadano era la misma que debía asumir como gobernante, un hombre justo hace un Estado justo "Para ser un buen gobernante se requiere el mismo tipo de excelencia como para ser un hombre bueno" (Isócrates, 1979).

En el discurso sobre la paz, recuerda a sus conciudadanos los requerimientos necesarios para ser felices: tener una ciudad segura, poseer lo necesario para vivir y la necesidad de apartarse de la guerra. El llamado de Isócrates en el Discurso sobre la paz, propende por recuperar la felicidad como proyecto político, exige el alejarse de la posibilidad de la guerra "¿Sería suficiente para nosotros vivir con seguridad en la ciudad, tener abundancia de medios, el mismo parecer entre nosotros mismos y gozar de buena fama entre los griegos? Yo creo que con estas cosas la ciudad sería completamente feliz" (Isocrátes, 1979, p. 15). Apartando la guerra se consigue la felicidad como búsqueda de la acción política auténtica, que lleva a la inmortalidad a la ciudad. Si 
la ciudad no sucumbe al vicio, entonces alcanza la perpetuidad como propósito de la comunión de espíritu. De acuerdo con la proclama del discurso sobre la Paz, Isócrates recuerda la íntima conexión de la religión y la política. En este contexto del pensar ético religioso griego cuyo imperativo es social antes que particular:

Y conviene que las ciudades mucho más que los simples individuos cultiven las virtudes y rehúyan los vicios. Porque un hombre que sea impío y malvado podrá morir antes de pagar el castigo de sus errores. Las ciudades, en cambio por su inmortalidad sufren la venganza que viene de los hombres y de los dioses (Isocrátes, 1979, p. 42).

La figura del juez el que adjudica por antonomasia, se le ha de comprender desde la exigencia de justicia más allá de cualquier reivindicación personal, la adjudicación es un asunto de los dioses. Por otro lado, la divina justicia también se erige como la virtud primera en el orden general, y por lo tanto es asumida, en términos actuales, como principio referente y fundante más allá de ser considerado como un mero valor. Es necesario dentro del debate contemporáneo acerca de la naturaleza del derecho, precisar la urgencia de volver a ubicar la supremacía de la justicia como quiera que la historia del orden social ha estado marcada por la reivindicación de los ideales de igualdad sobre la base de la justicia, de ahí que un compromiso es el retorno a la reflexión jurídica en la que "la justicia es el núcleo axiológico del derecho" (Botero, 2005, p. 31).

Los discursos de Isócrates consagran la teogonía y la cosmovisión sobre la justicia, como eje de la moral y política en Atenas; sus disertaciones tienen la exigencia y la pretensión de restaurar el orden justo, a través del rol del juez y del orador, es un rol importante y decisivo en la polis, esta tarea según Platón, está reservaba a los nobles y virtuosos. La labor del orador, como labor que incide en la adjudicación, conllevaba una notable exigencia moral, tanto de la vida privada de la persona como de su vida pública: "Es de necesidad que el orador sea justo y que el 
hombre justo quiera que sus acciones sean justas", reflexiona Platón sobre el rol del orador, ya que no puede ser un charlatán, pues este aleja a los ciudadanos del cuidado de su alma y del logro de la vida de excelencia y noble. El persuador tiene la exigencia de hacer mejores, de ennoblecer al auditorio al que se dirige (Platón, 1970, p. 198). Porque son a quienes se exige virtud, noblesa, vida buena. La adjudicación por ser asunto que se debe debatir entre dioses y hombres, es discurso, se adjudica en y por el decir. Por lo tanto el discurso del juez, del litigante y de todos los ciudadanos que intervienen en la labor del adjudicar, en tanto persuadores, debe emanar y ser creado, a partir de la convicción y la certeza de que la justicia es virtud, porque se configura en el centro espiritual de la polis.

Quien padece injusticia es una víctima, porque se ha humillado su dignidad, y no merece vivir de esta manera. Isócrates, en el discurso forense contra Eutino advierte de esta condición de víctima de injusticia "No me faltan motivos para hablar a favor de Nicias, aquí presente; ocurre que es amigo mío, que se encuentra en apuros, que es víctima de una injusticia” (Isócrates, 1979, p. 66). Para evitar la injusticia (la hybris) la obligación del juez, de las partes como oradores, es la de asumir la obligación de escribir bien, de ser altamente razonable y ordenado en el pensar. "Pero lo que sí considero innoble es el hecho de no hablar ni escribir bien sino de modo innoble y mal” (Platón, 2007, p. 153). El persuador, cuya vida sea honorable y justa, permite que en su pensar solo tenga una referencia auténtica: la verdad, y como a consecuencia de ella, logre conducir la acción social y política de sus conciudadanos hacia la virtud. No puede por lo tanto congraciarse con lo trivial e intrascendente. Platón, quien avoga para que se haga justicia como Isócrates, plantea que justo es buscar restaurar lo perdido, pugnar para que la víctima reciba lo merecido, es decir, lo justo que va más allá de que se le resarsa materialmente un daño. Hacer justicia es recobrar la dignidad y el honor lesionados frente al ultraje padecido, porque atenta contra el domino sereno de sí, al exponerlo a los vicios que afectan su alma; es el caso que se ventila en la causa adelantada 
por Isócrates, en favor de un hombre pobre pero noble que pertecene al partido democrático y que ha sido golpeado por el joven aristócrata Loquites. La víctima parece no recibir lo justo por la desigualdad social y el amparo al aristócrata, todo en menoscabo del alma vapuleada, esta es la denuncia y el reclamo de Isócrates.

La jerarquía en la polis está dada por el alto sentido del honor y la dignidad, y es por ello por lo que se apela, la indignación se anida en la injusticia recibida porque lesiona la virtud del alma. "Ahora vengo a recibir de él satisfacción, no por algún daño causado por los golpes, sino por el ultraje y deshonor, que es precisamente lo que tiene que causar la más honda indignación a los hombres libres” (Isócrates, 1979, p. 91).

Llegar a la excelencia, al $\alpha \rho \varepsilon \tau$, Areté, en tanto "atributo propio de la nobleza" designa excelencia. (Jaeger, 1994, p. 12) es la esencia de la nobleza, comporte un aprendizaje de las virtudes, entre la que se destaca de manera preponderante la justicia; esta lo informa, le da forma como hombre perfecto. "El concepto de justicia, considerada como la forma de la areté que comprende y cumple todas las exigencias del ciudadano perfecto" (Jaeger, 1994, p. 109). El ciudadano libre y noble llamado a la perfección debe aprender el principio de la justa distribución y la forma en que ha de prevalecer en cada caso. Los hombres libres se forman en la justicia, porque esta se conquista, el hombre no es justo per se, se hace justo, se construye en las acciones que exigen el colectivo.

Por lo que esta virtud se halla encaminada esencialmente al servicio público, cuyo fin es el bien común, núcleo esencial de la ciudad. En el caso de los jueces, si ellos son justos con otros entonces son justos consigo mismos, hacen honor a su propia virtud. "Es propio de jueces inteligentes que, al votar lo justo en asuntos ajenos, simultáneamente ayuden a los suyos propios” (Isócrates, 1979, p. 93). La mesura sobre las acciones exige la recta razón de quienes juzgan, recta razón que implica discernir a quienes es justa y dable ciertos bienes. "Para lograrlo, necesita discernir quién debe qué bien a qué personas en distintas 
situaciones” (Macintyre, 1994, p. 117). El valor de la justicia en tanto divinidad y virtud, postula la política igualitaria: todos los hombres libres y nobles son iguales, independientemente de sus posesiones; gozan de iguales garantias, esta es la clave de la felicidad de la polis que la protege de cualquier desastre que pueda acaercer al colectivo en el cual estan incorporados, como uno solo: "Y, después que nos dimos mutuas garantías, tras reunirnos en un mismo lugar, trazamos una política tan bella e igualitaria que ningún desastre nos sobrevino" (Isócrates, 1979, p. 83). Los ideales de la polis, como democracia auténtica descansan en el reconocimiento del otro, en el respeto, la distinción y la dignidad inherentes a su persona. Es irritante y corrompe la polis si los ciudadanos libres no reciben un trato igual y justo, si son privados de sus derechos legales, si se impide su participación en las magistraturas. Todo lo anterior sería un atentando contra la ley misma y el principio igualitario:

Pero aún lo más terrible de todo sería que en una ciudad democrática no alcanzáramos todos los mismos derechos, sino que pudiéramos participar en los cargos públicos, pero nos priváramos a nosotros mismos de los derechos legales (...) pero, en el momento de votar concediéramos más importancia a los que tienen dinero (Isócrates, 1979, p. 94).

Sugiere Aristóteles, que quien es injusto actua de manera viciosa, parte de lo vicioso de su accionar es que es un individuo ambicioso que lo hace insaciable. El vicioso no tiene límites, por lo que se halla vacio, y esta vacuidad lo conduce sin pudor a infringir la ley. El injusto termina apartándose del principio igualitario, porque su deseo lo embelesa, lo desequilibra, arrastrando consigo el vicio de la víctima, siendo doblemente injusto: "lo justo sea lo legal y lo igual: "es injusto tanto el que quebranta la ley como el ambicioso y no igualitario (...) lo justo es lo legal y lo igualitario, y lo injusto lo ilegal y lo no igualitario” (Aristóteles, 2004, p. 153). La pátrios politeía en la que está incardinado el juez como el que adjudica en y para la virtud, como la instituida por Pericles, quien él mismo representa el ideal de lo que ha de ser un 
verdadero y auténtico ciudadano sabio, prudente y justo, mencionado por Isócrates en el discurso sobre el tronco de caballos "y fue educado por Pericles, al que todos estarían de acuerdo en considerar como el más prudente, más justo y más sabio de los ciudadanos”. (Isócrates, 1979) consagraba la ciudadanía, una nueva ciudadanía desde derechos inherentes a la persona-persona y a la persona-polis, en la doble construcción de honorabilidad individual y colectiva. El individuo y la polis en unidad sinérgica son iguales en prudencia, justicia y sabiduria, por lo que la acción política externa de la Polis, es igual a como si se comportara un individuo virtuoso, justo. De lo anterior se desprende que la regulación de convenios celebrados con la Polis y sus iguales otras polis-estados, están bajo el amparo de los ideales de vida buena. Los iguales entre iguales como esencia de la democracia: "En la tragedia Fenicias (...) Eurípides ponía en boca de Yocasta una referencia, mientras describía el valor de la justicia, a la necesidad de honrar la igualdad (istes) entre amigos (phílous... phílous), ciudades (póleis... pólesi) y aliados (symmákhous... symmákhois)” (Buis, 2011, p. 9).

Bajo esta perspectiva, en el mundo griego es claro que la justicia como principio, y cuando se despliega en la adjudicación, tiene la perspectiva

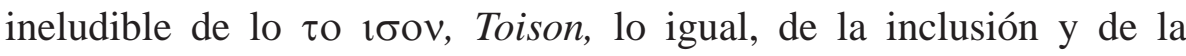
afirmación. En el discurso sobre el Aeropagítico, exhorta Isócrates a los areopagitas a recuperar la dignidad y el estatus democrático, en momentos de crisis y corrupción como la que atraviesa Atenas. Clama por volver a los ideales de la pátrios politeía, recordando los pilares de la justicia y la igualdad:

Lo que más contribuyó a que gobernaran bien la ciudad fue que, de las dos igualdades que se conocen, una la que asigna lo mismo a todos y otra la que da a cada uno lo conveniente, no ignoraron cuál es la más útil, sino que consideraron injusta la que estima igual a los buenos y a los malos (Isocrátes, 1979, p. 57).

Se establece por lo tanto la manera como se concebía la idea de lo igual (Toison) lo simétrico, pero desde las asimetrías que constituyen y 
configuran la pluralidad y la diversidad de los hombres libres y nobles de la democracia griega. Aclara Isocrátes que en el ejercicio de la razón práctica de la justicia, es decir, la acción virtuosa por excelencia, se ha de atender a dos igualdades: una general, para toda la polis y otra particular entendida como lo conveniente y necesario para el ciudadano en concreto. Estas simetrías-asimétricas tenían asignaciones de derechos distintos. El juez, como hombre virtuoso debe poseer el criterio de distinción, de proporcionalidad y de la mensura, como garantes de la adjudicación de lo justo. La justicia igualitaria implica que en los casos concretos que sean análogos obtengan una respuesta parecida; y cuando los casos sean en su extensión y proporción diferentes se dé una respuesta en esa medida y dimensión, lo que se ha de estructurar como proporcionalidad desigual. Administrar o adjudicar justicia se entiende como cuestión de virtud, de razón, de justo medio, de igualdad en lo igual, lo igual se ha de tratar igual "los casos con diferencias proporcionales de merecimiento sean tratados según esa proporción (...) una distribución es justa si y solo si preserva, entre dos casos en los que los recipientes sean desiguales en su mérito una distribución proporcionalmente desigual” (Macintyre, 1994, p. 127).

Aquellos ciudadanos que participan en la adjudicación de justicia, bien como jueces, bien como oradores, tienen la tarea no solo de resolver situaciones privadas o conflictos públicos (por ejemplo con otras polis) sino que cumplen la misión de la psykhagogía, entendida como seducción o cuidado ético del alma de los otros. El orador persuade y conduce el alma hacia la vida bella o noble tokalon esa es la adjudicación. La vida en justicia se edifica sobre el dominio moral como deseo comunitario de la polis, que anticipa la eternidad. Se afirma la esperanza en la posibilidad y realización del areté. El proyecto social de justicia, la hace el phronimos ${ }^{2}$, el hombre recto, un ciudadano capaz de discernir las verdades convenientes y necesarias para hacer

2 De phronesis como capacidad de sopesamiento de la verdad, al momento de aplicar justicia. 
el bien; como hombre inteligente ${ }^{3}$ (cuyo esfuerzo racional le permite argumentar) ayuda mediante el ejercicio de la justicia a lograr el bien común, lo correcto y provechoso para todos. Por el contrario, hombres necios pueden llegar a creer que la justicia no es posible; que termina siendo una práctica hermosa ante los ojos de los dioses, pero inviable para la vida de los hombres, especialmente los que escogen la maldad como senda ${ }^{4}$. Es fundamental que se exhorte la práctica de la virtud, por parte de los hombres rectos y se reprocha a los necios pensar en los réditos que trae la injusticia y la maldad "En cambio, son los más insensatos cuantos piensan que la justicia es una hermosa práctica y más grata a los dioses que la injusticia, pero creen que vivirán peor los que la usan que los que prefieren la maldad". Planteamiento también presente en la República de Platón (Isócrates, 1979, p. 20).

La justicia, su administración y adjudicación implica esfuerzo constancia y firmeza, es voluntad perseverante para mantener y sostener el dominio de sí, se advierte el trabajo que implica para el ciudadano la vida justa en la polis. El ciudadano hace un compromiso de lealtad y rectitud: “Aristóteles devuelve las cosas a su verdadera medida mostrando que el elemento que sustenta el saber ético del hombre es la orexis, el "esfuerzo", y su elaboración hacia una actitud firme (hexis)" (Gadamer, 2003, p. 384). Según Platón ser leal y recto involucra ir en contra de la propia voluntad, reprimirla pues es más fácil llevar la vida por el sendero del vicio, de la vanidad y el deleite personal porque se presentan siempre como lo bueno y deseable por todos; las pasiones son poderosas el caballo negro es vigoroso y tentador para todos:

Si queremos comprender mejor que quienes practican la justicia lo hacen contra su voluntad, por la impotencia de obrar injustamente, hagamos una suposición: demos a ambos, al hombre justo y al injusto, el poder de obrar como les plazca y, observémoslos después para ver a dónde los conduce su pasión. 
No tardaremos en sorprender al hombre justo, como éste, por el deseo de tener más que los otros, deseo que toda naturaleza persigue como algo bueno, pero que la ley reprime por la fuerza para que subsista la igualdad (Platón, 2006, p. 173).

Lo justo es un arduo trabajo sobre el espíritu, es la lucha contra sí mismo por vencer los vicios; es el llamado a vivir la templanza como opción, implica el sometimiento a las normas y al autogobierno sobre las pasiones, la comida, la bebida y el amor. "Para la mayoría de los hombres, ¿no consiste principalmente la templanza en ser sumisos con quienes los gobiernan y saber dominarse en los placeres de la bebida, del amor y de la mesa” (Platón, 2006, p. 227). Los actos de justicia nacen de las almas probas que se han cultivado desde temprana edad en las virtudes de la justicia, la prudencia, la fortaleza y la templanza. De ahí que la función del que imparte justicia, del que adjudica no puede dejarse en manos de los jóvenes porque no poseen experiencia sobre las acciones de la vida. Y esta inexperiencia puede llegar a ser causa de injusticia, y motivo de inmoralidad. Debe ser tarea de los ancianos, pues el buen juez por su experiencia y sabiduría ha logrado deliberar y tener la claridad sobre el vicio que representa la injusticia, injusticia de quienes la cometen y de quienes la padecen, además han de ser ejemplo de a-temperancia: "El buen juez no debe ser un hombre joven; es necesario que sea un anciano y que haya llegado con el tiempo a saber lo que es la injusticia, no por tenerla arraigada en su alma como un vicio personal” (Platón, 2006, p. 263). Estos hombres honorables representan lo que Isocrátes (1979) en el discurso Panatenaico (XII) designa como bien educados, ya que son capaces de discernir sobre lo conveniente de tratar con dignidad y justicia a los que los acompañan, soportan las vanidades de los demás, son atemperantes, en últimas, hombres completos: “¿a quiénes llamo personas bien educadas, puesto que rechazo los oficios, las ciencias y el talento? (...) De quienes poseen una disposición de espíritu ajustada (...) de ésos afirmo que son hombres inteligentes, completos y que tienen todas las virtudes” (Isocrátes, 1979, p. 208). 
Una de las expresiones más contundentes de la justicia en la polis son sus leyes $(\lambda \varepsilon \psi \varepsilon \sigma)$. Los ciudadanos deben honrarlas y dar la vida incluso por ellas. Las leyes y de manera entronizada: la Constitución representa la unidad, el sentido y el alma misma de la ciudad como sistema político sus ciudadanos están bajo su amparo y sometimiento, es su guía en todas las actividades de la vida social; preserva los bienes y es la inteligencia colectiva, la espiritualidad de la pátrios polietía: “el alma de una ciudad no es otra cosa que su constitución (...) tienen que acomodarse a las leyes, los oradores y los ciudadanos corrientes y actuar de tal manera que cada uno se mantenga en los límites de la Constitución” (Isócrates, 1979, p. 55). La Constitución señala también los límites de la acción ejemplar de sus prohijados, se entiende como la expresión espiritual del querer de la bondad. Merece censura y es causa de ofensa que algún ciudadano siquiera piense en suprimir las leyes) o violarlas “con este individuo, que se atreve a violar las que están escritas, a ése lo dejaréis ir sin castigo. Pero no obraríais con justicia, ni de manera digna de vosotros, ni tampoco de acuerdo con vuestras opiniones anteriores” (Isócrates, 1979, p. 79).

Las leyes son el propósito anímico religioso y político de legisladores, tribunales, jueces, oradores, en fin, de todos. Las leyes como diosas tutelares guían la adjudicación. El juez al preservar la ley guareciendo lo conveniente para la virtud y prohibiendo lo necesario para evitar los vicios y las injusticias, confiere vida a la justicia, "cuando disputan los hombres recurren al juez; y dirigirse al juez es dirigirse a lo justo, pues el juez pretende ser como la justicia dotada de vida” (Aristóteles, 2004, p. 161), el juez también iguala quitando y adicionando como tarea de

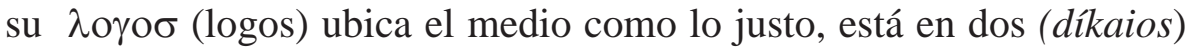
el juez es un dikastés, porque iguala en la asimetría "Cuando un todo se divide en dos, las gentes dicen que tienen lo suyo precisamente cuando toman la parte igual. (Y lo igual es medio entre lo más y lo menos conforme a la proporción aritmética)” (Aristóteles, 2004). La Polis como lugar espiritual anida las aspiraciones de los ciudadanos, como deseo común porque habite la justicia, porque la adjudicación 
sea justa; su espíritu está en tensión entre el vicio y la virtud, entre el ciudadano y el conjunto, la medicina y la enfermedad; las antinomias se resuelven teniendo a la justicia como la salud del alma, salud que se adquiere en la medida que el ciudadano esté inserto en la vida política "La justicia es la salud del alma, siempre y cuando concibamos ésta como el valor moral de la personalidad” (Jaeger, 1994, p. 637). La enfermedad del alma consiste en alejarse de las normas, y quedar por fuera de la posibilidad del amparo de la justicia, y de la vida política como garantía de cuidado y autogobierno. En el seno de la Polis, según Platón, es en donde se atempera el alma, y se hace dueño de sí, al hacer que, en el alma resida lo bueno y lo menos bueno, pero ha de lograr que lo mejor y noble predomine. Pero si no logra dominar lo menos bueno entonces se transforma en un esclavo de sí: “a consecuencia de la mala educación, o de las malas compañías, lo bueno, muy aminorado, es dominado por lo menos bueno, se dice, y con ello implica un reproche y un oprobio (...) es esclavo de sí mismo e intemperante” (Platón, 2006, p. 431a). El hombre con valor, es aquel que lucha contra su thymôs, que es la parte del alma en donde están las emociones, las pasiones fuertes de la vida y que definen al hombre justo del injusto, de esta proceden sentimientos a manera de antinomias, como se presenta y se expresa la vida en ambigüedades, entre amor y odio, amistad y venganza, alegría y enfado, osadía y temor "El thymôs es, sobre todo, la fuente de las emociones. La amistad y los sentimientos de venganza, la alegría y la tristeza, el enfado y el temor, todos emanan del thymôs” (Bremmer, 2002, pp. 48-49). Cuando el alma injusta se restaura lo hace a través del temor divino que se expresa en el pudor y la vergüenza "leyes aptas para lanzar en justicia, contra la torpe audacia que allí irrumpa, aquel nobilísimo temor, el temor divino que hemos llamado pudor y vergüenza" (Platón, 1999, p. 73), el orden sacrificado, con su ofensa.

La adjudicación del juez es un ejercicio moral reconciliador. Es sospechoso que se requieran tantos jueces y médicos en la ciudad, algo no está funcionando en la ciudad, es un indicio de su enfermedad "¿un indicio más seguro de una educación mala y viciosa en una ciudad que 
la necesidad de hábiles jueces y médicos, no solo entre los artesanos y gente vulgar sino entre quienes se precian de haberse educado como hombres libres? (Platón, 2006, p. 405b). Con tantos jueces y médicos se evidencia que la formación ética y moral es defectuosa, con vicios, es demostración de la falta de virtud y justicia personal. ¿№ te parece vergonzoso y prueba evidente de una educación defectuosa el verse obligado a recurrir a una justicia extraña, por falta de virtud y de justicia personal, convirtiendo a los demás en dueños y jueces de uno mismo? (Platón, 2006, p. 405b). El obrar justo del legislador y del juez en su adjudicación estará mediado por la imposición de penas proporcionadas, es decir, adecuadas o moderadas. Lamenta la polis, tener que legislar conductas tan ofensivas a los dioses. "Se dan casos sobre los que resulta terrible y nada grato el legislar, pero que no pueden quedar fuera de la legislación, tales los homicidios de los parientes cometidos ya por propia mano, ya por medio de insidias con toda voluntariedad e injusticia, los cuales ocurren mayormente en ciudades mal regidas y mal educadas, pero que también ocurrirán alguna vez en un país donde nadie podría esperarlos” (Platón, 1999, p. 872d) y que los ciudadanos no puedan refrenarse, por actuar según Platón como bestias fieras, alejadas del querer político, como el bien común, como lo esencial de la ciudad.

\section{La adjudicación en la reflexión medieval}

El medievo ubica al juez dentro de la perspectiva del teologismo jurídico propio del momento, donde la transversalización del pecado como ofensa a Dios, encuadra la adjudicación. De ahí que la falta o conducta reprochable continúa (como en mundo griego) con una carga simbólica dentro del escenario religioso, que para la época es la tradición cristiana. Se ha de imponer la justicia Divina, a través del poder político del rey, quien juzga en nombre de Dios en la tierra: "Ninguno de los reyes debe creer que el reino que administra le ha sido dado por sus progenitores, sino que debe creer sincera y humildemente que le ha sido dado por Dios” (Sevilla de, 1951, p. 499). El rey, el príncipe se configura por tanto en el centro de la acción social, es la sede de los poderes concentrados en su majestad y potestad, su mandato, en el que 
está la administración, adjudicación de justicia, expresa los quereres y los propósitos de la voluntad que reside en la Providencia. Sus intenciones están conducidas por los fines a los cuales está inscrito por ser la expresión primera de los quereres de Dios en la tierra, en él se concreta la imagen y la razón divina:

Es, pues, el príncipe, como muchos le definen, la pública potestad y cierta imagen en la tierra de la Divina Majestad (...) el poder del príncipe es de tal manera de Dios, sino que Él usa de ella a través de una mano subordinada, proclamando en todas las cosas su clemencia o su justicia (De Salisbury, 1983).

Por lo tanto el príncipe tiene asegurada y garantizada su legitimidad y legalidad, además de estar desterrado cualquier cuestionamiento, o asomo de duda acerca de sus disposiciones, porque en últimas son los preceptos del Altísimo. Se desprende de ello que como gobernante solo debe rendir cuentas a quien lo consagró para este encargo, no al pueblo a quien imparte y adjudica justicia, de esta manera como gobernante y juez, en su cabeza que residía estas labores, era que reposaba lo propio del querer supremo, su poder es absoluto y no ha de estar sujeto a las leyes, solo obedece y da cuenta de sus acciones a Dios: "Este poder es absoluto y soberano, porque no está sujeto a otra condición que obedecer lo que la ley de Dios y natural mandan (...) el rey no puede estar sujeto a sus leyes” (Bodino, 1992). Para el siglo XIII Tomás de Aquino hace consideraciones acerca del lugar del juez e inserta en esta la reflexión de la justicia, del derecho y la ley en el tratado de la moral, porque el ejercicio de adjudicación del juez, es acción de la razón práctica como disposición del hombre ante la autoconciencia de sus acciones y por supuesto ante la recriminación cuando estas se apartan de la razón, de la recta razón que conlleva la justicia. Por lo que en el juicio, el juez declara o determina "El juicio no es otra cosa sino cierta declaración o determinación de lo justo” (Aquino, 1956, pp. II,II, cuestión 60 art. 5) lo que es justo, en tanto que está instituido en el derecho positivo, como lo está la ley divina o razón de Dios. El Juez actúa, por potestad humana y divina, conforme a derecho. Y este derecho por la escritura 
como ley positiva divina y humana, según Tomás de Aquino, otorga fuerza y autoridad "la ley escrita contiene e instituye el derecho positivo, dándole toda la fuerza y autoridad” (Aquino, 1956, pp. II,II, cuestión 60 art. 5) al togado. Este al proferir la sentencia, como ejercicio de su acción práctica, al adjudicar el derecho o la ley, como orden de la razón, al caso particular lo constituye en intérprete de las leyes escritas:

quien profiere un juicio, de algún modo interpreta las leyes, aplicándolas a un caso particular. Y a la misma autoridad corresponde el establecer las leyes y el interpretarlas. Y así como no se puede establecer una ley sin autoridad pública, así tampoco sin ella se puede dictar un juicio (Aquino, 1956, pp. II,II, cuestión 60 art. 6).

El juicio es expresión de la autoridad pública a toda la comunidad, autoridad legitimada porque la ley natural está inscrita en su razón, y lo lleva a actuar siempre en atención al bien común. La idea del bien común en aplicación de la justicia, y de la potestad otorgada al juez, se configura y trasciende todas las formas de lo social entendida como la relación de la parte al todo "la justicia particular se ordena a una persona particular, que respecto a la comunidad es como una parte para el todo" (Aquino, 1956, pp. II,II, cuestión 61 art. 1), y en la pretensión justa y por lo tanto ética de sancionar las injusticias. Así la justicia atraviesa toda la vida en conjunto como exigencia y regulación, además de ser garantía del bien común, de ahí que, nada que implique la relación con los otros puede estar sustraído de la protección de la justicia, se comprende que esta asuma formas concretas como: justicia conmutativa y justicia distributiva:

...la justicia conmutativa (...) ordena las relaciones mutuas entre las personas privadas (...) como el todo se relaciona con una de sus partes, y así se relaciona lo comunitario con cada uno de los individuos; y es la justicia distributiva la que ordena tal relación, que consiste en la distribución proporcional de los bienes comunes (Aquino, 1956, pp. II,II cuestión 61 art. 1). 
Siendo el concepto de proporción el que determina las relaciones justas y la justa circulación de los bienes, los referentes para que se piense la justicia en una dimensión menos restringida, son las figuras de los comerciantes, que pese a su reprochable actividad, impactan en el colectivo social medieval, se constituyen en nuevos actores sociales, porque también conquistan el espacio del nuevo orden de la ciudad. Las sanciones, como ejercicio de adjudicación, están inscritas dentro de estas clases de justicia, por lo que estas deben atender a sus requerimientos, los atentados a estas han de ser el contenido de lo que se sanciona, así, el castigo es proporcionado, en tanto recompensa "Lo sancionado indica una igual recompensa en castigo con la acción precedente; y por lo mismo se aplica principalmente a las acciones injustas, como cuando alguien hiere a otra persona, o la golpea, merece entonces ser golpeado" (Aquino, 1956, pp. II,II cuestión 61 art. 4) en la conmutación como en la distribución. La sanción en la perspectiva de la justicia conmutativa iguala, equilibra con la justicia de la pena las acciones injustas, así las penas restauran, atendiendo a la proporcionalidad como justa medida, como simetría. "Pagará ojo por ojo y viviente por viviente” (...) y así cuando alguien daña a otro en su propiedad, es castigado con un daño de la misma naturaleza” (Aquino, 1956, pp. II,II, cuestión 61 art. 4).

De ahí que la adjudicación se trata de adjudicación como simetría. Por lo que al acto ilícito le corresponde igual sanción, es decir, lo mismo, porque iguala las magnitudes del daño causado con el castigo -o dañorecibido, pecado con castigo para la redención. La recompensa que se otorga con la sanción causada por la injusticia cometida, es equitativa, como forma conmutativa: lo justo y lo sancionado. "En todos estos casos debe haber una recompensa siguiendo la norma de la equidad, por justicia conmutativa, de manera que si a alguno se le quita algo, se le recompense dándole lo mismo” (Aquino, 1956, pp. II,II cuestión 61 art. 4). Por otro lado, en algunos casos, se ha de atender a que la sanción en perspectiva de la justicia distributiva, sea asimétrica, porque el castigo deber ser más, de creciente entidad o magnitud que solo igualar, deber ser mayor el castigo: 
...no siempre la sanción es igual en especie a la falta: pues en primer lugar podría alguien herir injustamente a una persona mayor, y entonces el castigo sería mayor en especie que la ofensa; y así quien golpea a un gobernante, no sólo es golpeado, sino que recibe mayor castigo. Igualmente cuando alguien daña a otro contra su voluntad en una propiedad, le causa mayor daño que si sólo le quitase aquella cosa, y no sufriría en realidad ningún daño el agresor si sólo tuviese que restituirla (Aquino, 1956, pp. II,II cuestión 61 art. 4).

Como en el caso de las ofensas en las que el infractor con sus acciones reprochables causa daños graves o sensibles a las indicaciones de un buen cristiano, como verbigracia: herir a una persona mayor, robar a una persona en su propiedad, golpear al gobernante. Estas ofensas merecen mayor castigo porque afecta con esta conducta a toda la comunidad, “se le castiga obligándolo a restituir más de lo que robó, puesto que en tal caso no sólo perjudicó a una persona privada, sino también a la comunidad política, al infringir la seguridad de su tutela” (Aquino, 1956, pp. II,II cuestión 61 art. 4). El daño a toda la comunidad es un daño sensible porque lesiona la seguridad y la justicia de todos. La sanción distributiva no iguala, es asimétrica porque su interés en justicia es la proporcionalidad entre las cosas y las personas atendiendo a su dignidad, las magnitudes que sopesa son de igual entidad o al menos de la misma importancia "la justicia distributiva (...) no se atiende a la igualdad entre un objeto y otro, sino a la proporcionalidad entre las cosas y personas” (Aquino, 1956, pp. II,II cuestión 61 art. 4).

En la justa proporción del castigo, en la ponderación de entidades de igual y legítimo valor se ha de tener en cuenta que, según Tomás de Aquino, y dentro del teologismo jurídico medieval fuerte, considera que la pena de muerte es saludable y necesaria para el bien mayor que significa el beneficio colectivo, "cuando lo requiere la salud del cuerpo humano, es necesario amputar un miembro canceroso que puede corromper los otros miembros, lo cual consideramos saludable y digno de alabanza” (Aquino, 1956, pp. II,II cuestión 64 art. 2). Por lo anterior, 
una vida pecadora bien se puede sacrificar, porque se hace en beneficio de la vida de los demás cristianos que se ven en riesgo; es lícito matar al pecador, al infractor porque esta acción conviene y es necesaria para la salud de todo el cuerpo social que se ha de preservar "Por tanto, si algún hombre es peligroso y corruptor de la comunidad por su culpa, puede matarse laudablemente para la salud y el bien común de todo el cuerpo comunitario” (Aquino, 1956, pp. II,II cuestión 64 art. 2) pero esta muerte justa se debe cumplir por parte del gobernante, no por un particular, porque este no cumple con la adjudicación justa. Se asemeja al cuerpo, y si un miembro se corrompe, este se debe sacrificar, por lo tanto matar al infractor será digno y objeto de elogio, porque el malhechor arruina el bien colectivo al cometer crímenes graves. Igualmente en esta perspectiva de la adjudicación justa y proporcionada, se encuentra la pena de amputación, "la amputación de un miembro, aunque fuera en detrimento de un cuerpo, sin embargo fuera necesario para el bien común (...) podría privársele de algún miembro por algunas faltas menores” (Aquino, 1956, pp. II,II cuestión 65 art. 1) destinada para aquellos que comenten delitos, incluso si las ofensas son menores; pero es justa la mutilación cuando es ejecutada por parte del gobernante, en la medida que es él quien actúa en beneficio de la comunidad. Que al infractor le sea cercenado el miembro culpable, canceroso, causa de pecado es una acción justa. Otras formas de castigo justo son los azotes, siempre y cuando estén dirigidos a la corrección y a la disciplina; en el caso del encarcelamiento, este como sanción y como prevención está en coherencia de proporción, pues con esta se cumple el propósito de que el malhechor no continúe con su acción dañina "El encarcelar a un hombre o el detenerlo de alguna manera, es ilícito, a no ser que se haga por orden de la justicia, sea como castigo o para evitar que el reo cometa otros daños” (Aquino, 1956, pp. II,II cuestión 65 art. 3).

Pondera el Aquinate, también como propio dentro del teologismo legal, en el cual está inserto los delitos-pecados, que deben tener mayor sanción, como ejercicio de proporcionalidad distributiva, así señala que el juez debe adjudicar mayor castigo: cuando el infractor daña a 
muchos, cuando hiere al gobernante, porque este representa a todo la comunidad. Ha de tener mayor castigo cuando se lesiona a alguien que está relacionado con otra persona, porque el mal se ocasiona a los dos y se considera un mal mayor: "cuando se inflige la injusticia a una persona relacionada con otra de algún modo, tal injusticia se comete contra las dos personas; y por tanto en igualdad de circunstancias, el pecado es más grave” (Aquino, 1956, pp. II,II cuestión 65 art. 4).

De esta manera se debe imputar, adjudicar mayor castigo por la gravedad del mal causado o bien atendiendo la dignidad de la persona. El juez cuando sanciona, en adjudicación dice Tomás de Aquino, crea derecho, crea una ley particular, esta instauración normativa la hace porque en su labor de intérprete, contribuye con la justicia como voluntad de la recta razón, por distinción y claridad de lo justo y bueno "El juez es intérprete de la justicia” (Aquino, 1956, pp. II,II cuestión 67 art. 3). El juez al crear derecho como autoridad pública, lo crea de manera legítima, por lo que su sentencia es coactiva, eficaz y vinculante:

La sentencia del juez equivale a una ley particular acerca de un hecho concreto. Y así como la ley ha de tener fuerza coactiva (...) la sentencia del juez ha de tener fuerza coactiva, por la cual ambas partes se ven obligadas a cumplir la sentencia del juez; de otro modo el juicio no sería eficaz (Aquino, 1956, pp. II, II cuestión 67 art. 1).

Un aspecto interesante que señala el lugar y el rol que desempeña y ubica el juez en el medievo, es que el castigado, a quien este enjuicia ha de estar sujeto al juez. Esta sujeción es paradigmática porque tendría dos lecturas, en un primer lugar ampara ciertas garantías a quien es sometido al juez, para ser juzgado, y de esta manera las leyes pueden operar como límite legal y moral, pero por otro lado el estar sometido a la voluntad del juez, que en últimas cumple el querer de Dios, le deja al ejercicio soberano y al arbitrio del juez, pues este como autoridad suprema tiene la potestad para juzgar, y por su calidad y condición, este juzgamiento es justo, todavía más en los casos en que no está prevista una pena. Esta discrecionalidad, esta arbitrariedad bien puede ubicarse 
en los límites tenues de la transgresión de las mismas leyes que imparten y adjudican:

Un decreto de Alejandro III estableció el principio de que un delito por el cual la pena canónica no estuviera prevista, sería sometido al arbitrio de los jueces (...) Inocencio IV adoptó la distinción entre crímenes y penas. Ordinarias y extraordinarias (...) “...los jueces tienen el derecho de 'transgredir' las leyes...". Si bien esta afirmación fue más discutida para las penitencias, el arbitrio del confesor también habría triunfado en relación a ellas (Zysman, 2012, p. 62).

Así siempre estaba vinculado al juez por delegación o jurisdicción ordinaria, su potestad humana y divina, era legítima, además de seguir con la intención y el hilo conductor del juez en el mundo griego, su quehacer sigue siendo el conductor del alma de los hombres, su actividad consiste en la atemperancia y contención de los vicios y pecados, se trata de corregir las sendas que han trazado las acciones ofensivas de los malhechores. El togado al proferir el castigo, en justicia y proporción, corrige porque es superior "Pero es debido a la justicia el que se obedezca al superior en todo aquello en lo que es superior. Y el juez, como ya se ha dicho, es superior del acusado respecto a todo lo referente al juicio" (Aquino, 1956, pp. II, II cuestión 69 art. 1). También corrige porque adjudica en el juicio al condenado, como quiera que busca el bien justo; las penas de esta manera, como responden a la íntima convicción del juez, a sus criterios de virtud, además de estar investido de la voluntad de Dios. Ha de tener lucidez para discernir la gravedad de las acciones ofensivas que atentan contra la justicia, y con la certeza de la necesidad de instituir el orden y la igualdad que es reflejo de la Providencia, se trata de que el juez cumpla los designios que le están deparados, por la razón al hombre como creatura divina, y que consisten en no hacer el daño a otros: "la justicia constituye la igualdad haciendo el bien, o sea, dando a cada uno lo que le corresponde; y la justicia conserva la igualdad ya constituida evitando el mal, o sea, no haciendo ningún daño al prójimo” (Aquino, 1956). 
La labor de la adjudicación como responsabilidad y acción moral conlleva que el juez realice o actualice el ejercicio de la virtud de la prudencia, como razón práctica; con una consecuencia para los que están sujetos a su toga, es que los castigos adjudicados por el juez cuidador y guía de las vidas de los hombres, que han infringido el bien moral, sean en mayor medida arbitrarios, pues estas sanciones dependerán del sentido y comprensión del hecho oprobioso por parte del juez. El discernimiento será a su arbitrio, pues ponderará la mayor o menor ofensa o pecado que se ha causado a Dios y a los hombres, al cielo y a la tierra. Los castigos adjudicados son lícitos, proporcionados, justos por los nobles propósitos que amparan al togado, tanto por las leyes humanas, como divinas. De seguro que en la acción moral del discernimiento, y según cada caso concreto, el juez aplicará de acuerdo con la acción, y a las necesidades de redención de cada ofensor, pecador. Configura en la sentencia, el contenido moral reformador requerido de ahí que en mayor medida, y en sentido fuerte en el contexto medieval, los castigos sean arbitrarios porque siempre apuntaban a la búsqueda de la justicia, que merece según ofensa, y de acuerdo con la conciencia cristiana de quien está delegado para ello. Esta labor moral que se concreta en la adjudicación de los castigos ha sido parte de la indagación por la conciencia y el querer dañoso de la voluntad, del trasgresor:

Así Santo Tomás trata minuciosamente la cuestión de saber sobre qué ha recaído la voluntad para que el hecho sea punible (...) Se Trata de saber tan solo si había previsto y querido todas las consecuencias del hecho; se trata de su objeto y muy poco de su causa primera (Saleilles, 2005, p. 54).

El togado en la ponderación del juicio del infractor, logra entrever gracias a su dignidad y condición, la conciencia y la acción que llevó al acto maligno, acto que decidió como consecuencia del libre albedrio que lo define, como ser racional. La subjetividad del juez, su discrecionalidad está directamente proporcionada a la fidelidad a la virtud cristiana y a la ruta de la justicia como guía en sus fallos, con la garantía de cumplir el proyecto divino. 
En la adjudicación medieval del siglo XV, con el teologismo punitivo, legal de carácter fuerte, la aplicación al caso concreto por parte de los jueces, adquiere renovados sentidos y símbolos por la presencia enérgica de la Inquisición, “su creación en 1478 o 1480, después de gestiones con Sixto IV iniciadas años atrás, coincide casi exactamente con la formación de la Hermandad nueva o Santa Hermandad en 1476" (Tomás y Valiente, 1969, p. 27). Así se comprende que delitos-pecados como la brujería cobran un inusitado sentido y efecto en la vida del conjunto social, donde la mujer es estigmatizada como causa del mal social, por ser perturbación anímica de la comunidad, también graves delitos-pecados como el comercio y la usura, que por ser vicio, como exceso arruinan la virtud y el alma justa, con ello desagradando a Dios, “adición al decreto de Graciano, monumento de derecho canónico en el siglo XIII: Homo mercator nunquam aut vix potest Deo placere (El mercader no puede-o difícilmente puede-agradar a Dios) (...) "es difícil no pecar cuando se hace profesión de comprar y vender” (Le Goff, 2004, p. 84). Ante esta manifiesta y clara sinergia entre pecado y delito, la adjudicación medieval permitió la institucionalización de las penas arbitrarias en las cuales el castigo físico y cruel además de la pena de muerte eran las directivas, y que se universalizaron una vez que se dieron por agotadas las penas pecuniarias. Como parte de la brutalidad del castigo, en la adjudicación se consolidan los suplicios, bajo el amparo y la licencia de la iglesia cristiana, con el beneplácito y la salvaguarda para que no hubiese obstáculos en su ejecución:

no se los moleste ni obstaculice por autoridad ninguna, sino que amenazará a todos los que intenten molestar o atemorizar a los Inquisidores, a todos los que se les opongan, a esos los rebeldes, cualesquiera fuere su rango (...) con la excomunión, la suspensión, la interdicción y penalidades, censuras y castigos aún más terribles (...) puede por Nuestra autoridad acentuar y renovar estas penalidades, tan a menudo como lo encontrare conveniente, y llamar en su ayuda, si así lo deseare, al brazo Secular (Kramer, 1975, pp. 4-5). 
Se destaca en este contexto punitivo el papel de la mujer como protagonista principal del delito de brujería, ella es la fuente fundamental de este execrable delito-pecado, toda la brujería proviene del apetito carnal que en las mujeres es insaciable "hay que nunca se hartan (...) para satisfacer sus apetitos, se unen inclusive a los demonios (...) no es de extrañar que existan más mujeres que hombres infectadas por la herejía de la brujería" (Kramer, 1975, p. 54). El deseo sexual de la mujer, según esta cosmovisión de reproche, no tiene atemperancia, por lo que ha de censurarse toda manifestación de su sexualidad femenina, para la mujer está negado este ejercicio de su dimensión humana. El varón es visto como víctima de la seducción perversa y malhechora de la mujer, que los arrastra sin piedad a cometer este pecado abominable, además de ser un delito contra la naturaleza divina, que habita en él, pues el varón ha sido bendecido por Dios para no pecar con la brujería:

...es mejor llamarla la herejía de las brujas que de los brujos, ya que el nombre deriva del grupo más poderoso. Y bendito sea el Altísimo, quien hasta hoy protegió al sexo masculino de tan gran delito; pues Él se mostró dispuesto a nacer y sufrir por nosotros, y por lo tanto concedió ese privilegio a los hombres (Kramer, 1975, p. 54).

La sexualidad insaciable de las mujeres, causa de los males de los varones, es maligna en muchos aspectos, en primer lugar se vuelve contra ellas mismas y las condena, y por otro lado las hace vulnerables a que sean infectadas, pecadoras y corruptas, además arrastran al mal a otros, que son los varones virtuosos y buenos. La brujería es un Delito gravísimo porque el daño que causan las brujas de manera libre y voluntaria por el pacto con el demonio, causan venganza, mal y daño "han firmado un pacto y contrato con el demonio, (...) dichas mujeres colaboran con el demonio, aunque están unidas a él por la profesión por la cual al comienzo se entregaron a su poder libre y voluntariamente” (Kramer, 1975, p. 23). Una de las primeras descripciones de la imagen de las brujas, como mujeres malignas, delincuentes y pecadoras, ya habían sido realizada por San Isidoro, quien ofrece en su Etimologice, cap. 9 una explicación al porqué del color negro que las define "Las 
brujas se llaman así debido a lo negro de su culpa, es decir, que sus actos son más malignos que los de cualquier otro malhechor”. Y señala uno de sus más fuertes poderes, que las caracteriza en toda su maldad, y es que estas pecadoras logran modificar el clima y doblegar a su antojo la naturaleza. Al manipular el medio, esta acción constituye una grave ofensa a la obra de Dios, y es en este acto diabólico donde se manifiesta el pacto con el maligno, que las hace irreverentes y por ello objeto de suplicios. Este poder es vituperable por el perjuicio que la violencia del clima causa en los cristianos: “Agitan y confunden los elementos con la ayuda del diablo, y crean terribles tormentas de granizo y tempestades" (Kramer, 1975, p. 21). El otro daño que causan las brujas a las creaturas de Dios, es el hecho que con sus artificios confunden la mente de los hombres, los manipulan de tal forma que los empujan a la locura, a un odio insano y a desmesurados apetitos; estas malignas mediante hechizos y pócimas llegan incluso a terminar con la vida de los buenos cristianos.

Agustín de Hipona en La ciudad de Dios, también dedica un espacio para describir y proscribir a estos humanos torcidos, brujos y brujas, ya que estos se aprovechan de los cristianos que en estado de debilidad, pierden la confianza en Dios, estos los enloquecen llevándolos al pecado y al delito "llevan a la locura la mente de los hombres que perdieron su confianza en Dios, y que con el terrible poder de sus malos encantamientos, sin pócimas ni venenos, matan a los seres humanos" (Kramer, 1975, p. 21). Estos seres ponen en estado de indefensión a los buenos cristianos presos de estas artimañas del maligno, este se apodera de ellos, los posee y esta posesión se refleja en sus acciones de hechizados, o bajo la influencia de encantamientos maléficos que los lleva a la muerte

Una mente que no ha sido corrompida por ningún brebaje nocivo perece a consecuencia de un encantamiento maléfico. Por haber llamado a los demonios en su ayuda, se atreven a derramar males sobre la humanidad, y aun a destruir a sus enemigos con sus encantamientos maléficos (Kramer, 1975, p. 21). 
Las mujeres al parecer son las portadoras del maligno y causan la perdición de las almas de los varones, estas infectan a los hombres con la brujería, y con ellos los hacen infieles, ambiciosos y lujuriosos, por ello cometen el más atroz de los delitos. De igual manera, las pecadoras, delincuentes padecen la brujería porque ellas infectan sus úteros, con el adulterio, la fornicación y los deseos lujuriosos en los que viven, contagiando la creación y la bondad de los cristianos a quienes persiguen "las malas mujeres, a saber, la infidelidad, la ambición y la lujuria (...) las adúlteras, las fornicadoras y las concubinas del Grande (...) infectan de brujería el acto venéreo y la concepción del útero” (Kramer, 1975, p. 54). Los pecados y los delitos perpetrados por estas brujas bien se podrían enlistar en distorsionar las mentes de los hombres al caer en sus bajas pasiones, en no concebir al dejar secar su útero o al destruir este. Otros delitos son la conversión o la mutación de los hombres en animales, haciendo que mediante encantamientos las mujeres no gesten o que aborten sus creaturas. Esta maldad es mayúscula porque incluso estas delincuentes ofrecen niños a los demonios, para sus artes de nigromantes, además de ofender la obra cristiana porque presentan animales y frutos para la realización de sus propósitos maléficos (Kramer, 1975).

Por lo anterior, estos procesos penales por el delito de brujería eran denominados los juicios de Dios, que siempre por estar cumpliéndose la voluntad de Dios son justos, no cabe duda que en estos procesos en contra de las brujas, había la garantía de estar castigándose a los malhechores siempre con justa causa "existe siempre una causa muy justa, aunque no la conozcamos (...) Y si en el resultado no podemos penetrar en la profundidad del juicio de Dios, sabemos que lo que Él dijo es cierto, y justo lo que É1 hizo” (Kramer, 1975, pp. II, 40), de ahí que no es posible que los jueces cristianos juzguen ni condenen a muerte a inocentes, porque en el caso en que un inocente fuese juzgado como culpable se trataría de una manifestación del demonio, y eso sería conceder mucho poder al mal. También no es posible que un inocente fuese juzgado por el delito de brujería, porque según el punitivismo 
medieval: Dios no permitiría que ocurriese tal infamia, ni siquiera el poder de Dios permitiría que fuesen investigados los buenos cristianos por delitos menores como robos y otras entidades sin importancia:

hasta hoy nunca se supo que ocurriese que una persona inocente haya sido difamada por el demonio hasta tal punto, que se la condenara a, muerte por ese delito (...) nunca se supo que una persona inocente haya sido castigada por sospecha de brujería, y no cabe duda de que Dios jamás permitirá que ocurra (...) El no permite que los inocentes que se encuentran bajo su protección angélica sean sospechados de delitos menores, tales como robos y otras cosas; tanto más protegerá El a quienes se encuentran bajo esa guarda, de la sospecha del delito de brujería (Kramer, 1975, p. 33).

Los juicios de Dios, en tanto justos permitían afirmar que todos aquellos que eran enjuiciados debían ser culpables del delito grave de brujería, y para desterrar algún asumo de duda, el sospechoso debía ser sometido a la purificación de su alma corrompida, que consistía en la aplicación del castigo físico o tortura, y si a causa del suplicio perecía, entonces se ratificaba la posesión del demonio, y la comisión del delito de brujería:

Y aquí se afirma que, si ese hombre fracasa en su purificación, se lo debe considerar culpable, pero tiene que ser objeto de una solemne súplica antes que se proceda con castigo de su pecado y se lo ponga en práctica (Kramer, 1975, p. 33).

La tortura para esclarecer la duda, no era injusta ni cruel y menos anticristiana, porque incluso sin que llegue a ser culpable el procesado, de todas maneras se le aplicará el suplicio para purificarlo, por el bien de su alma, y si no logra sobrevivir al suplicio, es que sin duda era culpable. Los juicios de Dios conllevan la sentencia de la pena de muerte, como purificación y salvación de la humanidad del demonio, del mal, la adjudicación del juez se trata de la adjudicación que Dios prevé para el pecador, la adjudicación es redención del alma del ofensor de ahí que es una santificación individual y colectiva. 
En los juicios de Dios se observa la legitimidad de la crueldad, la fusión entre delito y pecado y la consecuente arbitrariedad de las penas, en sus sentidos fuerte y débil, pues estaba bajo el criterio de bondad y los prejuicios de género de los varones medievales que juzgaban a las mujeres. Quizá el punitivismo medieval tenía incorporado como elemento armónico, necesario y subsecuente la represión, represión de los cuerpos objeto de la maldad de las brujas, represión del pensamiento, y represión extendida al tejido social, y sin duda a la política:

Plus tard, l'arbitraire paraît le meilleur moyen de mettre à jour la répression. C’est pourquoi, la pression romaine se fait plus forte. Dans les toutes premières années du XIV siècle, le principe même des peines arbitraires se laisse deviner dans certaines villes méridionales, ce qui constitue une transformation profonde des habitudes coutumières, une transformation qu'on devine également dans les ordonnances des souverains (Schnapper, 1973, p. 252).

La adjudicación medieval encuadrada en la crueldad, la arbitrariedad del castigo, como forma de aplicar castigos proporcionados y justos en el sentido de simetría, entre el delito y el castigo. Las penas arbitrarias, la fórmula de las penas arbitrarias resolvía el contexto del pecado que se instaura como delito, atendiendo en razón a la arbitrariedad que de acuerdo con el caso concreto, a las calidades de los delincuentes: “on punira selon l'exigence du cas, selon les démérites du coupable. Il est vain, semble-t-il, de multiplier les exemples pour prouver comment le roi est passé des peines comminatoires à des peines modulables et enfin aux peines arbitraires" (Schnapper, 1973, p. 256). Bien se sostiene que la punibilidad medieval, como adjudicación se define desde el teologismo penal, en el que la obligatoriedad de la ley penal que castiga el pecado como doble ofensa a Dios y a los hombres. Esta adjudicación fuerte tiene el propósito del sometimiento de la conciencia que se desvía, por lo que se justifica el castigo, que redime.

Con la irrupción de Lutero el mundo medieval y su cosmovisión teocéntrica, de manera sustancial son transformados, el pensamiento 
crítico del monje agustino, trae como consecuencia la entrada del denominado mundo moderno y del consiguiente giro teórico del derecho, del Estado, del ius puniendi y por lo tanto de la figura del juez y la adjudicación. Formando con ello la arquitectura jurídica compleja de la modernidad, y el encumbramiento del hombre y la razón.

\subsection{La adjudicación hoy}

La pregunta por la adjudicación en términos actuales precisa de lo que significó la incidencia fuerte de la figura del juez, dentro de la tendencia doctrinaria del positivismo, que se afincó hasta la segunda mitad del siglo $\mathrm{XX}$. Pues es desde el debilitamiento y de alguna manera el agotamiento de este enfoque que emerge una pluralidad de comprensión de este fenómeno, que conlleva la labor concreta a la que está sometido el togado, en los contextos de las sociedades complejas del siglo XX. Con la segunda guerra mundial, de cuyos horrores en parte se responsabilizó al positivismo, como quiera que cubrió de justificación el genocidio judío, y permitió que se afincara en el caso del derecho punitivo la retribución "la retribución fue vista como una forma de huir de los horrores de los que se responsabiliza al positivismo" (Bacigalupo, 2008). Otra de las calamidades, responsabilidad del positivismo, fue la marca que puso la gnoseología del derecho, en cuanto a la explicación y aplicación de la forma como el juez ha de aplicar el derecho al caso concreto, reducido a la quimera del silogismo. De esta manera su quehacer racional se trataba de seguir la ruta trazada, ya interpretada dentro del sistema cerrado, donde encuentra todas las respuestas al caso por dirimir: "Según esta teoría, la única tarea del jurista consistía en interpretar el Derecho positivo y desarrollar en un sistema cerrado, conforme a principios lógico-deductivos, los preceptos concretos de la ley, subiendo hasta los últimos principios y conceptos fundamentales” (Roxin, 2002, p. 17).

Ante la fractura que marcó el positivismo, y ante la revisión y crítica de la forma de pensar el derecho y de dar sentido a la adjudicación, se vio la urgencia de la entronización de la dignidad de la persona, y 
de manera especial a finales del siglo XX, la vuelta a los principios y a los derechos fundamentales como los pivotes que definen el Estado posmoderno. Este retorno, quizá sea temprano para mencionar un posible renacimiento, del vigor que adquiere la filosofía del derecho, y la ética en el contenido y el discurso que adquieren y requieren los amparos humanos como consecuencia de las discontinuidades de la posmodernidad, y los discursos abiertos y entre fronteras que conllevan que sus contenidos se amplíen en sentidos y salvaguardas. La construcción y reconstrucción de los derechos fundamentales en parte corresponde a la creación de los mismos que hacen los jueces. Quienes dentro de la teoría crítica del derecho, en su acción de razón práctica que se concreta en la adjudicación de aplicación de derechos y garantías, son incorporados a toda la red de producción de sentido y construcción simbólica del derecho, por lo que su rol, una vez agotados los debates entre jusnaturalismo y juspositivismo (como quiera que ninguna de estas escuelas están en las rutas de comprensión en la complejidad actual) recobra el lugar adecuado y correspondiente que ocupa, y el cual no ha de estar hiperafirmado al aparecer como la figura única a la que se reduce la práctica de la jurisdicción, por su actividad argumentativa racional. La adjudicación de este actor social no está a la deriva, ni tampoco lo suficientemente abierta como para que se pierda y termine siendo una labor solipsista, de autorreferencia, más allá del reconocimiento de su subjetividad. Parte de la paradigmática labor de la adjudicación, como quiera que se mueve entre la restricción y la apertura. Parte de la exigencia como supuesto, es que debe dar cuenta, debe argumentar de manera razonable su decisión y las consecuencias de esta, por lo que el juez no es un ejecutor sin más del estatuto normativo, pues el sistema normativo, la norma misma no tiene el propósito de resolver los conflictos complejos del nicho jurídico. Parte de la razonabilidad del juez es que ha de incorporar las construcciones sociales de la justicia y la paz social:

...el juez debe actuar aquí sin arbitrariedad; su decisión debe descansar en una argumentación racional. Debe haber quedado claro 
que la ley escrita no cumple su función de resolver justamente un problema jurídico. La decisión judicial llena entonces esta laguna, según los criterios de la razón práctica y las concepciones generales de justicia consolidados en la colectividad (Alexy, 2010, p. 58).

Los juristas han buscado metáforas, bien dentro de la mitología griega, o dentro de individuos con apellidos cotidianos, para poder dar forma a la comprensión del sentido del trabajo del juez, además de ubicar el contexto epistemológico e histórico al cual estas imágenes responden. También estas representaciones facilitan advertir las limitaciones y contradicciones que emergen dentro de un orden jurídico que tiende a estructuras más cerradas que abiertas, y con cierta predisposición a resistirse a la crítica, o al encuentro en los lugares de fronteras disciplinares. Estas iconografías ubican el horizonte en el cual los cimientos, fines y propósitos del juez precisan de corrientes o enfoques, que resultan por antonomasia los ideales en los cuales el derecho se justifica, como un sistema único de referencia y al cual los ciudadanos desamparados acuden para que pueda obtener una respuesta que puede resultar correcta. Estas representaciones de posibles jueces traducen las distinciones y los niveles de intereses políticos, económicos y sociales del grupo social al cual pertenecen y en el cual está inserto el sujeto al derecho, en su rol social y cultural de juez. Los acostumbrados debates acerca de las preocupaciones de las tendencias tradicionales entre iusnaturalismo e iuspositivismo, y su infinidad de divisiones, subdivisiones, cruces y transversalidades, en la perspectiva del avance del derecho en el siglo XXI, están siendo superados por el apabullante cambio de los dinamismos sociales que exigen actores sociales e intérpretes constitucionales en clave posmoderna:

...el tradicional debate entre las corrientes de pensamiento jusfilosófico tradicional, carece ya de relevancia e interés, porque ninguna de ellas en estado "paradigmático" se sostiene. Se producen así, distinciones y subdistinciones, matizaciones y cruces a través de los cualescomo señala Ost-se regresa siempre a un modelo clásico que permita 
reconstruir la unidad ideal del derecho en un punto único y supremo (Cárcova, 2009, p. 205).

Se afincó en la segunda mitad del siglo XX un pretendido debate Hart-Dworkin, del que ya no parece tan debate, pero que dejó una reflexión necesaria e interesante acerca de la adjudicación, y el rol del juez como actor social. La metáfora que usa Dworkin para describir la labor ideológica del juez, y que lo encuadra dentro de la problemática de la fundamentación de la adjudicación hoy, es la figura del dios Hércules, que se tiene que debatir en todas las situaciones, a la manera de los trabajos duros (athloi) o desafíos en los cuales debía probar su competencia para superar la adversidad "un athlos era literalmente una competición, en especial por un premio y, por extensión, una lucha o experiencia desafiante que implica grandes esfuerzos y conflictos (...) las arduas tareas que Heracles llevó a cabo para Euristeo" (Hard, 2010, p. 335). Este juez Hércules acepta todos los desafíos que le plantean las complejidades de la vida en conjunto, y que bajo el título de casos difíciles, este juez a la manera del dios mortal, siempre está listo para el reto del trabajo que le depara y para el cual siempre debe dar una respuesta correcta. Este modelo de juez-dios se erige en el modelo para seguir, porque de alguna manera, como Hércules, logra vencer la adversidad, Dworkin le interesa señalar, no el conflicto y las contradicciones internas además de las paradojas que este dios mortal contiene, sino la dimensión de suficiencia, racionalidad y de neutralidad como modelo que seguir, porque resulta siempre victorioso de los desafíos que le imponen. Pero esta metáfora de dios-mortal al aplicarla en la adjudicación como práctica concreta, no queda tan segura porque no responde a las vicisitudes y la puesta de la subjetividad del juez cuando aplica el derecho al caso concreto.

Este juez racional-neutral, además omnipresente, eficiente y competente está en crisis, es solo una quimera intelectualista, quizá un deseo de las aspiraciones colectivas porque las víctimas y los que se sienten desprotegidos obtengan justicia o al menos un tipo de resarcimiento de los daños y males recibidos. Este Hércules delineado y delimitado 
no convence aún más cuando, la experiencia social actual, gracias a la inmediatez de los medios, presenta acciones concretas de adjudicación de los jueces como paradójica, porque esta labor obedece a intereses políticos o económicos, lejos de las aspiraciones de equidad, justicia y paz social. Además ante las polémicas en las cuales se debate el conjunto social, como el aborto, la delincuencia juvenil, la eutanasia, el terrorismo, los jueces se ven confrontados, y no pocas veces sus fallos son desproporcionados y contradictorios caso a caso, porque reflejan sus apuestas sociales, políticas, religiosas, éticas, que no necesariamente coinciden con las expectativas y consensos sociales.

Menos convincentes aún, desde el punto de vista de dicha práctica, son la pretendida neutralidad de Hércules, el juez dworkiniano, y la defensa de la existencia de una respuesta correcta en cada caso judicial. El trabajo de los jueces consiste justamente en trazar límites difíciles, contingentes, entre posturas ideológicas opuestas frente a las cuales debe tomar partido (Kennedy,1999, p. 78).

En la reflexión acerca de la adjudicación ha rondado el mito de la unidad del derecho, herencia del positivismo, donde este se ha de comprender como un orden de sentido uniforme, omnicomprensivo de todas las conductas humanas, como una estructura que se replica y se cierra en sí misma, de normas a normas, y no hacen falta normas, porque no existen lagunas "no hay conducta humana que no pueda ser juzgada desde un punto de vista jurídico (...) De aquí resulta que un orden jurídico no puede tener lagunas” (Kelsen, 2004, p. 37). Este mito de orden unificado, de sistema uniforme donde conllevó también la exigencia de unidad narrativa, unidad de relatos y detentor a manera de referente de la moralidad política compartida por la unidad social, que no es otra que un orden jurídico igualmente "Lo que precisamente está en crisis, es esa visión del derecho y esa unidad así reconstruida” (Cárcova, 2009, p. 206). Pero esta pretendida unidad y estabilidad del sistema, no soporta los embates de los problemas y los debates en los que se hallan los grupos sociales posmodernos en los que las fracturas, los claro-oscuros y los variopintos de sus opciones e interpretaciones 
exigen, más que una estructura, quizá un sistema abierto y comprensivo de algunos de estos fragmentos de la vida colectiva.

Ante la complejidad de la posmodernidad, también se aboca el lugar del juez en este contexto, porque bien puede precisarse de una adjudicación que logre interpretar los retos contemporáneos que son móviles y dinámicos. En este contexto vale la discusión por la discrecionalidad amplia o restringida de los jueces, y lo que entra en juego porque se centra la disputa por la creación judicial, que se dirige siempre a dar una respuesta correcta, que se configura como la respuesta correcta para cada caso. La discrecionalidad está adosada a la adjudicación como un elemento de su estructura. Tanto que se puede plantear la función de discrecionalidad como advierte Dworkin, en función de la respuesta correcta para cada caso: “atacará la teoría de la función discrecional de los jueces enunciando la tesis de la respuesta correcta” (Dworkin, 1989, p. 13). Pero no se sostiene en el actual contexto una respuesta correcta de tipo unidireccional o hegemónica que detente las rutas de la comprensión del orden legal e incluso de la acción moral humana, más vale pensar de muchas respuestas correctas para cada caso, como se advierte en las garantías constitucionales que promueve el Estado social o el Estado social de derecho. La forma como se están co-construyendo los derechos fundamentales por parte de los jueces, ubica esta función de discrecionalidad de manera más fuerte que débil, y quizá lo que precisa la polémica es que esta sea cada vez más amplia, y que esta configuración, que antes estaba reservada de manera preponderante solo al legislador, ahora lo está en manos de los jueces. Esta fuerte discrecionalidad de los jueces, pese a las prevenciones que pueden llegar a consolidar el gobierno de los jueces, como expresión superlativa de adjudicación, ha de comprenderse como parte de la creación de un derecho vivo (lebendes Recht)

Es este derecho vivo, que constituye la estructura de la vida social, el que debe ser analizado, porque a él ajusta su conducta el súbdito, para quien la idea de compulsión representada por los tribunales es lejana y vagarosa. La vida social se vive en asociaciones y el Estado 
es sólo una más, aunque la principal, de las asociaciones en que los seres humanos se hallan incluidos (Cárcova, 2006, p. 67).

Pues la creación del derecho, como fenómeno de la cultura, corresponde a toda la comunidad de intérpretes que viven de manera cotidiana las respuestas o los silencios a sus expectativas de derechos y garantías. El derecho en el sentido crítico como práctica social discursiva, se ha de reconocer como creación cultural, política, simbólica y de sentido, que se afinca en las diferencias y en las inclusiones para que pueda dar cuenta de la dignidad y la paz social, "La construcción de sentido no es monopolizable, y la realidad social se constituye como múltiple y diversa” (Cárcova, 2009, p. 59). A consecuencia de ello se entiende el reproche a la labor hegemónica de creación del derecho, pues esta debe ser colectiva y abierta, y con ello se puede ir garantizando la disminución de la opacidad del derecho, que facilita que los ciudadanos no estén a merced de la voluntad y la supremacía de los operadores judiciales.

La expectativa de los ciudadanos frente a la creación del derecho, y como copartícipes de la democracia, es que los jueces en el ejercicio de su poder creativo y configurativo del derecho decidan siempre dentro de una ética civil pluralista de consensos, en aras de una sociedad más justa y más humana; y no solo como ejercicio formal de diseño de proposiciones normativas. En las actuales sociedades desiguales y asimétricas el reto es una adjudicación de la justicia desde las desemejanzas, más allá de las meras formalidades "la cuestión judicial casi siempre viene decidida por la doctrinal: que en las democracias razonablemente decentes solo en los casos más atípicos los jueces se ven obligados a hacer algo más que identificar y aplicar las proposiciones jurídicas verdaderas" (Dworkin 2007, p. 29). Quizá en la adjudicación actual sea necesario pensar los sentidos y las comprensiones de los jueces acerca del hecho de que él ha de estar sometido al orden legal y a la justicia, y si este sometimiento de su subjetividad es suficiente, para que decidan en cada caso concreto. El interés social frente a la adjudicación es paradójico, por un lado se comprende que No son ni máquinas ni sujetos trascendentales autónomos “- y no creer, desde lo profundo de nuestra imaginación, 
en la existencia de un sujeto trascendental y libre que "puede hacer lo que quiere", a diferencia de la imagen, más tradicional, de un robot programado por la ley” (Kennedy, 1999, p. 121) como quiera que están sujetados al orden o imperio de la ley, legitimado y justificado, pero, por otro lado, poseen también de manera legítima y justificada libertad de creación de nuevos sentidos e interpretaciones, tanto que en ciertos casos excepcionales se puede apartar de lo establecido y dar origen a nuevas consideraciones, texturas y coberturas de derechos y amparos fundamentales. Como respuesta a las emergentes formas del conjunto social y sus interrelaciones, móviles y dinámicas. La adjudicación es paradigmática y paradójica como afirmación del quehacer que implica la adjudicación, como acción de la razón práctica.

El terreno inestable de la adjudicación hoy del juez, como rol por desempeñar, le impide como intérprete constitucional, un poder mayor de comprensión, pues son estrechas las fronteras para poder apartarse de la creación del legislador para instaurar la propia en su lugar. En esta salvaguarda fuerte normativa, el juez no tiene de manera preponderante la potestad suprema interpretativa de la Constitución: "Es perfectamente razonable insistir en que a nuestros jueces no debe dárseles el poder de interpretar la Constitución de modo último y dotado de autoridad” (Dworkin, 2007, p. 71). Se supone que esta corresponde al legislador, sin embargo, los jueces de las Altas Cortes, como Corte de cierre se configuran en el garante de sentido último, es decir, que como ejercicio de su jurisprudencia sí tienen, aunque restringido, poder de interpretación de la Constitución, y a ellos se debe confiar esta como forma de realización de los fines de un Estado principiológico, o Estado social que protege la dignidad, la justicia y demás derechos humanos.

La paradojalidad de la adjudicación se evidencia también a manera de movimiento o nicho simbólico entre amplitud y restricción, entre discrecionalidad fuerte y débil, que implica que los jueces disponen de normas que le restringen incluso su propio, cotidiano y específico campo de acción 'La ley’ restringe en tanto que es uno de los elementos de la situación tal y como la percibo y siento. Es el ‘campo’ en el que 
debo ejecutar mi acción” (Kennedy, 1999, p. 130). La limitación del juez está cargada de manera amplia de múltiples sentidos, que recoge de directrices, principios, políticas, ideología, poder, normas éticas y morales, con los cuales puede cumplir su labor de decisión compleja que aplica al caso concreto. Él proyecta en lo social, un ejercicio fuerte de discreción, pese a que considere Dworkin que no tiene discreción porque en el caso de las lagunas, ha de resolver en la determinación de los principios: "cuando existen contradicciones o lagunas el juez no tiene discreción porque está determinado por los principios” (Dworkin, 1989, p. 15). Pero el asunto es que los principios no son cánones inamovibles, sino son creaciones históricas, limitados, contradictorios y están en constante puesta en ponderación y proporcionalidad, es decir, están siendo confrontados entre sí, con lo cual también son emergentes. Las fronteras entre sí no resultan tan radicales y demarcadas, como quiera que cobra mayor vigor la conexidad o la relatividad de estos a la dignidad y la libertad. Y el juez en la adjudicación posmoderna se enfrenta a esta ponderación de principios como creaciones dinámicas, paradójicas, simbólicas e indeterminadas en sentido débil, construidos según los retos y demandas de la vida en conjunto "todos los enunciados constitucionales, pero en especial los relativos a derechos, son inteligibles aunque adolecen de un cierto grado de determinación y, más concretamente, de la indeterminación que es propia de los principios” (Prieto, 2003, p. 223).

Las situaciones difíciles y complejas a las que se enfrenta el juez en la adjudicación hoy, resultado de las formas emergentes de la intersubjetividad, la tecnología, el consumo y la globalización, advierten cada vez más casos difíciles, en los cuales no solo existe una respuesta correcta, sino requieren más de una respuesta correcta. El derecho no resiste pirámides o líneas estrechas y directas, sino requiere red, fractalidad, estructura, sistema y subsistemas, porque estos casos paradigmáticos son en sí mismos expresión del mundo caótico, antitético y enmarañado, en el cual el ciudadano está inserto. Así reconoce la Teoría crítica del derecho que el juez, en ejercicio de la adjudicación 
actual, como forma paradójica, por el ejercicio del poder que está en juego, necesariamente tiene preferencias o motivaciones ideológicas.

Pero se puede afirmar (...) una preferencia, o motivación, o influencia, sin afirmar que el actor suscribe la ideología como proyecto, con un compromiso interno hacia ella en tanto algo que impulsar o defender frente a sus oponentes. La preferencia y las acciones que ella motiva o influencia no son más que una predisposición al hacer elecciones en los casos particulares (Kennedy, 2010, p. 37).

Estas preferencias del juez en la adjudicación, evidencian su sesgo, sus convicciones que no las hace públicas, las omite ${ }^{5}$ en su decisión, porque no iría al público a reconocer y desvelar sus opciones y apuestas éticas, políticas, religiosas, es un estratega, y habría el prejuicio de parte de quienes juzga por el prurito de imparcialidad. Por estas preferencias Kennedy propone tres tipos de jueces que responden al dilema de la ideología, el juez activista el mediador y el bipolar "Parece evidente que el juez activista restringido, el mediador y el bipolar están respondiendo a un dilema. Es verdad que mucha gente los condena de antemano, sobre la base de que ellos deberían 'simplemente decir no' a la ideología” (Kennedy, 2010, p. 69).

Otra figura de juez que recoge las intenciones de la teoría crítica del derecho y de la acción jurisdiccional como campo de sentidos, como derecho múltiple es, siguiendo a Ost, la figura de Hermes, en oposición a las figuras del juez Júpiter y el juez Hércules. El Juez Júpiter está en la cima de la pirámide de creación del derecho, aséptico, poderoso y trascendente. Mientras que el juez Hércules, quien no representa una figura poderosa, sino que su realidad es de ser semidiós, comparte los dos mundos el divino y el humano, así es por su particularidad fuente única de derecho válido, quien al momento de justificar sus decisiones hace confluir el razonamiento jurídico y el razonamiento moral, por la

5 Para no señalar que el juez despliega el mecanismo de defensa de la Negación, solo que omite sus preferencias por el peso de la estructura del contexto legal. 
revalorización de su rol. Hermes, como juez y como todo actor jurídico, configura red de sentidos de actores, roles es acción dialéctica, paradójica “una diversidad de los roles, una inversión de las réplicas (...) no es ni trascendencia ni inmanencia, sino, una vez más, se encuentra entre la una y la otra (dialéctica) o mejor todavía, paradoja (la una y la otra)" (Ost, 1993, p. 172) es interrelación simbólica cuya funcionalidad es la de hacer un buen derecho, entronizar los derechos individuales, como el derecho a la igual consideración y respeto, y reivindicar los derechos sociales, especialmente en sociedades desiguales, inequitativas y excluyentes.

La labor jurisdiccional como adjudicación hoy es acción de la razón práctica que se concreta, en una co-creación cultural, simbólica, y de alguna manera inserta una moral pública ciudadana. Una vez superado el positivismo y estando viviendo el pospositivismo la discusión de la relación entre derecho y moral está en otro nivel, en el de la indagación por el contenido y la polémica ética misma, no por la relación necesaria, pues está dada por descontado "los problemas de jurisprudencia son, en lo más profundo, problemas de principios morales, no de hechos legales ni de estrategia” (Dworkin, 1989, p. 51). La adjudicación en perspectiva crítica se trata de un juego de principios y estratégica, donde las racionalidades jurídicas se cruzan para hacer el derecho o los derechos, o apuntalar la fundamentación de un derecho que se hace en los tonos propios de la posmodernidad, porque solo de esta manera pueden dialogar con los sujetos y objetos múltiples y diversos, que configuran las normas y principios de todo orden del presente. Quizá una pregunta válida, de parte de los esencialistas, sea ¿cuál es el derecho que es? ¿A qué derecho habría que ser fiel?, la respuesta ha de ser fiel al derecho que se construya sobre la dignidad, los derechos fundamentales, las víctimas y demás apuestas del Estado social de derecho: "La fidelidad al derecho entra a jugar solo cuando hay un derecho al cual serle fiel. Cualquier operador jurídico, abogado o juez, puede influir en lo que el derecho “es” realizando trabajo jurídico” (Kennedy, 2010, p. 31). 
La teoría crítica del derecho considera que la discreción judicial, como ejercicio de adjudicación es múltiple, dinámica y sus comprensiones han de ser débiles, para acercar las tensiones de los extremos a las fronteras; pues en los linderos de manera paradójica no es el caos, ni la anomia sino la diversidad la que se manifiesta, pero tampoco el orden cerrado, sino el des-orden que se reproduce como respuesta a la complejidad: "Derecho múltiple en la que habría que fijarse; multiplicidad que no significa, sin embargo, anomia y anarquía. Habría que llegar a mostrar cómo el orden jurídico se nutre del desorden periférico, o incluso interno, y reproduce a su vez desorden” (Ost, 1993, p. 181). El fallo en el que se concreta la adjudicación múltiple, discrecional simbólica, también de manera paradójica es obligado, con un resultado obligado, porque se espera siempre que se pronuncie que falle, no puede dejar de hacerlo, de ahí que su escenario, por lo compleja de la adjudicación, es un escenario de tensión. "la adjudicación es un escenario donde se presenta con frecuencia una tensión entre la sentencia a la que el juez quiere llegar y lo que el derecho parece indicar, por lo menos a primera vista” (Kennedy, 1999, p. 81).

\subsection{Atenea: la metáfora de hoy}

Una metáfora que podría dar cuenta de las comprensiones de la adjudicación en la posmodernidad y que transita de manera obligada, por la mirada de género que se ha de insertar, es la diosa poderosa Atenea. La incorporación de la mujer a la actividad de la judicatura es definitiva, y como sujeto femenino, hace un derecho pensado, ponderado, particular, justo, con un sello que ha de superar los estereotipos y prejuicios de las sociedades predominantemente con presencia de varones en la administración de justicia. La presencia de mujeres en los Tribunales y Cortes Supremas se ha duplicado en Latinoamérica:

Aunque el poder judicial es un ámbito predominantemente masculino, entre 2001 y 2011 el número de magistradas pasó de un promedio de 10\% a 22,6\%, según los datos del último informe del Observatorio de Igualdad de Género de América Latina y el Caribe (OIG) (...) En 
la mitad de los países de América Latina la presencia de mujeres en el máximo tribunal de justicia supera el promedio regional de 22,6\%. Este es el caso de Venezuela (44\%), Puerto Rico (43\%), Costa Rica (35\%), El Salvador (33\%), Colombia (30\%), Nicaragua (29\%), la República Dominicana (27\%), Cuba (27\%) y Chile (25\%) (CEPAL, 2013).

Esta presencia de lo femenino ha de traer consecuencias para la práctica del derecho, para la configuración del derecho, el contenido simbólico, paradójico y paradigmático de los amparos fundamentales, y sin duda, otra visión del conflicto y la sensibilidad social. Así como Atenea, el juez (mujer - hombre) con la carga de lo femenino, ha de incorporar la fuerza en su acción práctica, como parte de su subjetividad, de su temperamento y personalidad, pues se trata de asumir la adjudicación como una guerra justa, el juicio es el escenario de combate, sofisticado, moderno además de artificioso. El derecho en parte es violencia, ejercicio de violencia aunque legítima "esta concepción del derecho está compuesta por retórica, burocracia y violencia” (Santos, 1998, p. 20). Atenea o Minerva, representa una forma contradictoria de ser y actuar, porque es la diosa de la guerra justa, protectora de la ciudad y a su vez es diosa de la sabiduría, encarna los valores vitales de un conductor de almas, un juez. Como diosa poderosa es fuerte, no teme a la guerra, participa de ella de manera protagónica, pero tampoco es belicosa per se, pues se diferencia de Ares, el dios de la guerra y la muerte. Atenea representa dentro de la guerra la valentía y la prudencia "un campo de acción diferente del de Ares. Mientras este personifica el furor bélico y la matanza, Atenea representa la valentía y la prudencia (...) ¡Salve, diosa! Concédenos suerte y felicidad” (Himnos Homéricos, 2001, pp. 188-189).

La adjudicación posmoderna bien encarna estas condiciones de Atenea, a manera de aparente antinomia: fuerza-sabiduría. Guerra y contención, el juez ha de incorporar en su acción la fuerza, que se despliega en el ejercicio de la coerción que le otorga la ley, además de la contención de las pasiones y vicios de los hombres, que ofenden con sus actos a 
los otros. Un juez posmoderno no puede ser débil, débil en la acción, débil en la teoría del derecho, débil en las opciones ideológicas, débil en el reconocimiento de su subjetividad, ni tampoco débil en la convicción que está creando derecho e instaurando nuevos sentidos de estos. En los contextos complejos de las sociedades posmodernas se requiere la valentía y la prudencia de Atenea para dar respuestas a los retos del Estado liberal de las desigualdades. Esta diosa poderosa también es creadora, es hábil, es estratégica no va a la guerra por la guerra misma, ella en posesión de la sabiduría logra, incluso, vencer al mismísimo Ares “b. Ares no siempre resultó vencedor. Atenea, una luchadora mucho más hábil que él, le derrotó dos veces en combate” (Graves, 2011, p. 140), vence a la guerra, a la violencia en su estado perfecto, pero ella no lo combate con las mismas armas, ella combate con estrategia y logra vencerlo. El juez combate con violencia, con el terror que le legitima la ley, y los dispositivos del Estado mismo, pero quizá como aspiración este juez Atenea, tendrá la labor de vencer la guerra que se establece en el juicio, con un sentido más allá de la mera y cruda retribución, que se ensaña con los que han de ser excluidos de la vida ciudadana, pero que voltea la mirada a las estructuras injustas de los que ostentan el poder y la dominación. La sabiduría del juez Atenea le permite otra mirada, pues su búho está siempre atento, para aplicar de manera alternativa castigos, sanciones, sentencias, para resolver las disputas, en donde ha de hacer valer la ley por medios menos violentos, incluso ante la perplejidad y dilemas del mundo de hoy, sustraerse a la guerra y no castigar, como quiera que las formas tradicionales de castigo ya están agotadas, pues la reincidencia y deslegitimidad de la sanción, dan cuenta de su fracaso.

La sabiduría de este juez Atenea se expresa en la comprensión y el sentido de quien es juzgado, que más allá de la etiqueta de garantista, protege al que está sometido, al vencido en la guerra, que adelanta en nombre del poder mayor del Estado. No podría nadie en los contextos punitivos de desequilibrio, apostar por un equilibro de fuerzas en la venganza legítima, sofisticada, en el que consiste el juicio "Su 
misericordia es grande: cuando los votos de los jueces quedan igualados en un juicio en el Areópago, siempre da un voto decisivo para dejar en libertad al acusado” (Graves, 2011, p. 140). Este coraje acompañado de sabiduría que caracteriza a este juez Atenea le lleva a estar de lado de la humanidad, pues pese a ser un infractor y de reconocer que sus actos no convienen al orden social y por el contrario es necesario que sean reprochados, requiere que atienda que algo de este puede ser considerado noble, bueno y posible de ser reconciliado. El estar cerca de la humanidad por parte de la poderosa diosa guerrera, pero sabia, conlleva una decisión por la conveniencia de instaurar y crear el derecho, otras formas de interpretarlo y así atender los retos de la sociedad de consumo, globalizada y virtual, ella ayuda a Prometeo a donar el fuego a la humanidad "Prometeo se dirigió enseguida a Atenea suplicándole que le dejara entrar en secreto en el Olimpo, a lo que ella accedió (...) salió a hurtadillas y donó el fuego a la humanidad” (Graves, 2011, p. 213). El afecto de la diosa guerrera-sabia por la humanidad, se manifiesta por el don de cura, ella otorga el don de resucitar a los muertos, para ello da sangre la Gorgona. De ahí que un juez Atenea, también cura, ha de sanar las heridas del tejido social con la guerra justa o juicio contra quien, con su inequidad, causa ofensa y transgrede el orden social. La cura es violencia, es fuerza, pero también tiene la expectativa de que sea superación. El juez se debate en el conflicto, los intereses, los vicios y pasiones de los hombres que comparten un espacio social. Este juez Atenea hace la guerra justa y además cura, ella cuenta con una lanza y un búho, la lanza es la violencia instaurada en la adjudicación, y el búho es la palabra, el derecho se hace y se dice, y con lo femenino esta carga adquiere una dimensión mayor. Lo femenino que aporta a la adjudicación el juez Atenea es la fuerza combativa de la palabra, del discurso, instituye la justicia, esa es su guerra, quizá los diversos colores y matices de la justicia hagan que su trabajo sea de enorme conflicto, y termine siendo incomprensible e incluso llegue a dejar una impronta de escepticismo y decepción en la sociedad de hoy. El juez Atenea no puede sucumbir (de manera fuerte o débil) a establecer la justicia, pues esta se impone a su investidura, 
que en últimas es la confianza social: "Pero Atenea, que había oído la súplica de Orestes (...) se apresuró a ir a Atenas, tomó juramento como jueces a los ciudadanos más nobles y convocó al Areópago para que se juzgara” (Graves, 2011, p. 99).

La labor judicial en tanto juez Atenea como adjudicación, como defensora de justicia, al crear discurso se desdobla en múltiples creaciones en el juicio, en donde se establece el escenario de combate: "cuestiones de hecho, cuestiones de derecho y las cuestiones entrelazadas de moralidad y fidelidad políticas" (Dworkin, 2008, p. 16) las disputas de manera preponderante se dan desde la perspectiva del hecho y del derecho, avivadas por la convergencia multidisciplinar, toda vez que el derecho es práctica social compleja. Acerca de la discusión sobre los asuntos de hecho, el tema es complejo porque se trata de hechos reales o históricos, que se han de reconstruir como acontecimientos del pasado, pese a que bien pueden resolverse por los medios de prueba. En la Adjudicación del juez Atenea, esta concede sabiduría y belleza más allá del sentido común de quien es juzgado "Paris: si tienes el sentido común suficiente (...) y que seas el hombre más bello y sabio del mundo" (Graves, 2011, p. 401), las subjetividades configuran una red de conceptos, de sentido y de sujetos, de ahí la fortaleza de la palabra que instaura comprensiones acerca del derecho, la política, el castigo, la ideología, la moral, crea realidades a manera de ficciones. "Dice Marí: "En base a estos procedimientos el derecho civil se forjaba dioses (consagración), hijos (adopción), cambiaba la vida en muerte (muerte civil) y la muerte en vida (restitución), las personas en cosas (capitis diminutio) y las cosas en personas (personificación)" (Cárcova, 2009, p. 36). Las ficciones, son parte de la sabiduría de Atenea, ella teje sentidos, instituye ficciones que permiten que existan convergencias, mínimos consensos, que facilitan la paz social, desde los mínimos de una ética pública. Atenea por el arte de la guerra justa es una estratega poderosa, armada, pero también dedicada a las artes manuales pacíficas, ella diseña, entrelaza: 
...virgen majestuosa, con un rostro hermoso aunque severo (...) aparece con una armadura completa coronada con un casco crestado de gran elaboración; lleva la égida que le sirve como coraza y manto y sostiene una larga lanza. La cabeza de la Gorgona estaba sobre su escudo, y su pájaro especial, la lechuza, aparecía posada sobre sus hombres (...) Como patrona de trabajos manuales pacíficos, Atenea presidía las artes y manualidades ejercidas tanto por hombres como por mujeres (Hard, 2010, pp. 245-247).

El juez Atenea como estratega de sentido, pues posee a manera de caja de herramientas entre las que cuenta el arsenal normativo, los principios de derechos, la ética, la moral, los dispositivos de poder, el escenario arquitectónico, y de manera fuerte, el juego del lenguaje que acciona la guerra justa que preside: "Llamaré también «juego de lenguaje» al todo formado por el lenguaje y las acciones con las que está entretejido" (Wittgenstein, 1999, p. 6). Su sentencia transforma la vida individual y la subjetividad, de quien es juzgado o de quienes son sujetos dentro del juicio, pero también es innegable que transforma la vida en conjunto y las subjetividades en red que conforman el tejido social. El juez Atenea cuenta en su discurso jurídico con una red de ficciones fundadoras y operativas, en la práctica, estructuradas como relato abierto, intertextual, con un razonamiento, o una ratio decidendi plural y paradójica, no única ni menos unidimensional, es tejida en red. Y parte del tejido es que emerge el inconsciente individual y colectivo como el Otro grande en Lacan: "El gran Otro designa la alteridad radical, la otredad que trasciende la otredad ilusoria de lo imaginario (...) Lacan equipara esta alteridad radical con el lenguaje y la ley (...) está inscrito en el orden de lo simbólico” (Evans, 1997, p. 143) a manera de narración o de relato con normas que desde los consensos éticos, políticos e ideológicos tienen el carácter de ser posiblemente y provisionalmente universalizables, a la manera de los juicios sociales, críticos sobre la realidad, que se comparten con otros en tanto univerzabilidad. "Los juicios morales adquieren significado descriptivo, incluso en la ausencia de mayordomos, en virtud de una importante característica lógica que 
comparten con otros juicios de valor llamada universalizabilidad (FR 2.2) (Hare, 1999, p. 23). La fuerza combativa, la fuerza del yo del juez Atenea radica en que pese a su subjetividad, no claudica, en la busqueda de alternativas a una apuesta superior: es posible que la subjetividad del agresor pueda ser movida hacia otras formas de expresión de su yo, de su violencia, de su creatividad, de sus pasiones y gustos individuales.

El juez Atenea cura, resana y reconcilia al ofensor mendiante la pena, el castigo, el límite y demás dispositivos que poseee, a manera de caja de herramientas, para restaurar la paz social; es inevitable el castigo o el límite de los actos, del ejercicio de la voluntad, en la Polis, la libertad de acción sin talanquera, ya ha sido convenida que no es posible, por lo tanto requerimos en aras de la posibilidad de vivir juntos, de un juez que cercene nuestro goce, nuestras pasiones y el desborde del deseo. El castigo de Atenea como diosa de la guerra justa, es que ella instituye con la palabra, con la fuerza de su argumento el cese de la guerra, de ahí que la fuerza de su justificación, en tanto acción es teleológica, “Toda acción es intencional (...) La acción tiene una estructura teleológica, pues toda intención de actuar apunta a la realización de una finalidad establecida" (Habermas, 2007, p. 105) intencional porque su finalidad es reconstruir el tejido social fracturado, si sus fallos son justos. El juez en la adjudicación con el castigo ha de apostar por la restauración de la subjetividad, más allá de los deseos desbordados, de ahí que el castigo tendría que apuntar, de manera certeza como la lanza de Atenea a atemperar a apaciguar los excesos que conllevan a quien decide transgredir, o a extender de manera amplia y sobrepasada su ambición y egoísmo. La sentencia ha de acertar para mitigar la violencia, la ira encendida, la irritación, el terror, el fanatismo sin más, a la manera de una sentencia de la diosa Atenea que en medio de la guerra justa, ella ordena a Aquiles, como guerrero también que se refrene, que calme su cólera, que cese la disputa, que enaltezca su racionalidad, que pare el odio y la venganza, al fin y al cabo es de dioses calmar las pasiones y son las bestias las que se arrastran en el odio y el desquite. Quizá 
en términos del mundo posmoderno, la adjudicación desde la reflexión de la filosofía del derecho, sea la orden que funda el autogobierno, el dominio de sí, que hace posible la paz social, y los valores de la ética ciudadana. Atenea ordena el domínate a Aquiles, pese a estar en medio de la guerra justa, del ejercicio de la violencia, obedece refrena tu thymôs, como alma de los deseos y el desenfreno: "Díjole Minerva, la diosa de los brillantes ojos: "Vengo del cielo para apaciguar tu cólera (...) Ea, cesa de disputar, no desenvaines la espada e injúriale de palabra como te parezca (...) Domínate y obedécenos” (Homero, 2009, p. 5) y Aquiles presa de la ira, como guerrero que es, decide obedecer pese a la ira que lo invadía “aunque el corazón esté muy irritado. Obrar así es lo mejor” (Homero, 2009, p. 5). Si el juez Atenea logra, a través de la adjudicación con penas alternativas, justas y proporcionadas, de que el violento, el que transgrede logre cambiar su subjetividad, en donde él dé cabida al autocontrol, al autogobierno y transforme su thymôs, de seguro será posible la paz social, como uno de los fines del Estado social.

El juez Atenea por la sabiduría que despliega creatividad en la adjudicación, es un creador de relatos, resultado de la selección de normas, principios, de las narraciones de los otros y del Otro. En la sentencia subsiste un relato, su propio relato "al tiempo de formular su propio relato seleccionando, reorganizando, “editando” la multiplicidad de relatos del proceso, el juez debe decidir cuáles son las normas aplicables al caso. Por lo general se tratará de un set de normas, de un subconjunto normativo que asociará reglas de procedimentales con disposiciones de fondo” (Cárcova, 2009, p. 40). Es válido pensar que en sociedades posmodernas, expuestas, públicas por lo que no será el mismo relato para los litigantes que para los jueces. Una actitud de sabiduría para el juez Atenea, es que su fallo como ejercicio de violencia, ha de apuntar con el ímpetu, la certeza y la necesidad de quien lanza una piedra necesaria para evitar la violencia excesiva, reprochable e indigna la piedra de la sabiduría y la ponderación o sophronister 
que otorga cordura en medio de la confusión y la incertidumbre. Esta sophronister transformadora, reconciliadora, instaura otros sentidos a la transgresión, atenúa la ira:

Heracles habría matado también a su anciano padre, crimen aún más grave a los ojos de los griegos, de no haber sido por la pronta intervención de Atenea, que le aturdió lanzándole una piedra; esta piedra, conocida por el nombre de sophronister (es decir, piedra de la sabiduría o de la ponderación) (Hard, 2010, p. 333).

La adjudicación del juez Atenea tiene un precario sentido de la verdad, por el carácter abierto y constructivo del derecho, hace que los jueces en sus decisiones estén contribuyendo con la filosofía del derecho, como reflexión urgente y necesaria en la posmodernidad. "Es así como la opinión de cualquier juez es en sí una filosofía del derecho, aun cuando esa filosofía se encuentre escondida y el argumento visible esté dominado por citas y listas de hechos” (Dworkin, 2008, p. 74).

\section{Conclusiones}

La adjudicación como tarea de la acción práctica del juez, ha tenido unas consideraciones fuertes a lo largo de la historia porque, sin ser la figura central de la vida social, sí juega un rol importante por las consecuencias en la construcción del tejido social, en la creación y aplicación concreta del derecho y la justicia, además de las comprensiones éticas, políticas y espirituales que son compartidas.

La adjudicación en el mundo griego está definida por la unidad simbiótica entre derecho y religión, la ley y la espiritualidad, como una sola expresión de la vida individual y colectiva. El juez representa la voluntad y la protección de los dioses, que no tienen otro interés que los hombres sean virtuosos y que la Polis, como expresión religiosa común coadyuve en la virtuosidad del alma de cada ciudadano, que se concreta en actos de justicia, como expresión del bien mayor. De esta manera, 
los dioses tutelares del derecho como Zeus, las Parcas, juzgan, actúan y son protagonistas en el momento de juzgar las almas. En este contexto de adjudicación Platón, Isócrates y Aristóteles señalan la necesidad de que el Juez, como hombre justo restaure el orden perdido por los vicios y las pasiones de los hombres injustos.

La adjudicación del medioevo está signada dentro del marco del teologismo jurídico, donde está unido a manera de acciones comunes ofensivas, el pecado como ofensa a Dios y el delito, encuadrados en el mismo reproche. Es el mismo nicho simbólico griego, del escenario religioso, que para la época es la tradición cristiana. No son los dioses griegos los que juzgan las acciones de los hombres, sino es el Dios del Cristianismo quien lo hace a través de sus gobernantes instituidos para ello. Es una adjudicación como simetría igual delito-pecado igual sanción, la crueldad y la violencia sobre el cuerpo, el dolor, es parte de la expiación y de la salvación del alma del delincuente pecador. En este contexto punitivo el papel de la mujer por ser protagonista del delito de brujería, es fundamental por el apetito carnal que es insaciable. Isidoro de Sevilla, Salisbury, Santo Tomás de Aquino, Bodino representan el pensar la adjudicación como justicia y derecho en el medievo.

La adjudicación en términos posmodernos, ubica la figura del juez, desde una pluralidad de comprensiones del derecho y la justicia, en los contextos de las sociedades complejas del siglo XX. La creación del derecho, como fenómeno de la cultura corresponde a toda la comunidad de intérpretes que viven de manera cotidiana las respuestas o los silencios a sus expectativas de derechos y garantías. El derecho en el sentido crítico como práctica social discursiva, se ha de reconocer como creación cultural, política, simbólica y paradójica porque atiende a los movimientos del poder. La subjetividad, las apuestas éticas, políticas y espirituales definen la adjudicación de los jueces hoy por hoy. Una metáfora que podría dar cuenta de la posmodernidad y que transita de manera obligada, por la mirada de género que se ha de insertar, es la diosa poderosa Atenea, diosa de la guerra justa y la sabiduría que lanza la piedra sophronister, piedra de la sabiduría y la ponderación. 


\section{Referencias}

Alexy, R. (2008). El concepto y la naturaleza del derecho. Madrid: Marcial Pons.

Alexy, R. (2010). Teoría de la argumentación jurídica. Lima: Palestra.

Aquino, S. T. (1956). Suma Teológica, Tomo XII. Madrid: Biblioteca de Autores Cristianos BAC.

Aquino, T. d. (1988). Suma de Teología, II-II. Madrid: BAC.

Aristóteles . (1999). La política . Madrid: ALBA.

Aristóteles. (2004). Ética a Nicómaco. Madrid: Alianza.

Bacigalupo, E. (1996). Manual de derecho penal. Santa Fe de Bogotá: Temis.

Bacigalupo, E. (1 de mayo, 2008). http://www.ortegaygasset.edu/ fog/ver/306/circunstancia/ano-vi---n--16---mayo-2008/colaboran-eneste-numero. Recuperado el 25 de mayo de 2014, de Baudrillard, J. (2009). El crimen perfecto. Barcelona: Anagrama.

Bauman, Z. (2010). Tiempos líquidos. Barcelona: Tusquets Editores S.A.

Bauman, Z. (2011). Vida de consumo. México: Fondo de Cultura Económica.

Bodino, J. (1992). Los seis libros de la República. Madrid: Tecnos.

Botero Bernal, A. (2005). La jeraquía entre principios generales del derecho: la historicidad y la culturalidad del principio de justicia. Revista de Derecho, 29-68. Universidad del Norte. 
Bremmer, J. N. (2002). El concepto del alma en la antigua Grecia. Madrid: Siruela.

Buis, E. (2011). Sobre gnomos y gigantes: Los tratados grecorromanos y la igualdad soberana de los Estados como ficción histórico-jurídica. Buenos Aires: Manuscrito clase doctorado.

Cárcova, C. M. (2006). La opacidad del derecho. Madrid: Trotta.

Cárcova, C. M. (2006). Materiales para una teoría crítica del derecho. Buenos Aires: LexisNexis Abeledo-Perrot.

Cárcova, C. M. (2009). Las teorías jurídicas post positivistas. Buenos Aires: AbeledoPerrot.

CEPAL. (1 de marzo de 2013). Se duplica el número de juezas en los tribunales de la región en una década. Notas de la CEPAL, N. ${ }^{\circ} 75$. Recuperado de http://www.cepal.org/notas/75/Titulares2.html

De Salisbury, J. (1983). Policraticus. Madrid: Nacional.

De Sevilla, S. (1951). Etimologías. Madrid: BAC.

Dworkin, R. (1989). Los derechos en serio. Barcelona: Ariel.

Dworkin, R. (2007). La justicia con toga. Madrid: Marcial Pons.

Dworkin, R. (2008). El imperio de la justicia. Barcelona: Gedisa.

Evans, D. (1997). Diccionario introductorio de psicoanálisis lacaniano. Buenos Aires: Paidós.

Feteris, E. (2007). Fundamentos de la argumentación jurídica. Bogotá: Universidad Externado de Colombia.

Gadamer, H.-G. (2003). Verdad y método. Salamanca: Sígueme.

Graves, R. (2011). Los mitos griegos 1. Madrid: Alianza. 
Gregorio, V. (1963). Dictatus Papae. En R. García y B. Llorca. Historia de la Iglesia católica, 2. Madrid: Católica.

Habermas, J. (2007). Verdad y justificación. Madrid: Trotta.

Hard, R. (2010). El gran libro de la mitología griega. Madrid: Esfera Libros.

Hare, R. (1999). Ordenando la ética. Barcelona: Ariel.

Himnos Homéricos. (2001). La “Batracomiomaquia”. España: Gredos.

Homero. (2009). La Ilíada. México: Porrúa.

Isócrates. (1979). Discursos I. Madrid: Gredos.

Isocrátes. (1979). Discursos II. Madrid: Gredos.

Jaeger, W. (1994). Paideia. México: Fondo de Cultura Económica.

Kelsen, H. (2004). Teoría pura del derecho. Buenos Aires: Eudeba.

Kennedy, D. (1999). Libertad y restricción en la decisión judicial. El debate con la teoría crítica del derecho (CLS). Santafé de Bogotá: Siglo del Hombre.

Kennedy, D. (2010). Izquierda y derecho. Buenos Aires: Siglo Veintiuno Editores S.A.

Kramer, H. S. (1975). Malleus Maleficarum (El martillo de los brujos). Madrid: Orión.

Le Goff, J. (2004). Mercaderes y banqueros de la Edad Media. Madrid: Alianza.

Lipovetsky, G. (2006). La era del vacío. Barcelona: Anagrama. 
Lipovetsky, G. (2008). La sociedad de la decepción. Barcelona: Anagrama.

Macintyre, A. (1994). Justicia y racionalidad. Barcelona: Ediciones Internacionales Universitarias EIUNSA S.A.

Ost, F. (1993). Júpiter, Hércules, Hermes: tres modelos de juez. DOXA, (14), 169-194.

Platón. (1970). Gorgias. Bogotá: Venus.

Platón. (1999). Las Leyes. Madrid: Centro de Estudios Políticos y Constitucionales.

Platón. (2006). República. Buenos Aires: Eudeba.

Platón. (2007). Fedro. Buenos Aires: Losada.

Prieto, L. (2003). Justicia constitucional y derechos fundamentales. Madrid: Trotta.

Roxin, C. (2002). Politica criminal y sistema del derecho penal, (2 ${ }^{\mathrm{a}}$ ed.). (Trad. Francisco Muñoz Conde). Buenos Aires: Hammurabi.

Sabine, G. (2002). Historia de la teoría política. México: Fondo de Cultura Económica.

Saleilles, R. (2005). La individualización de la pena. Bogotá: Leyer.

Salisbury, d. J. (1983). Policraticus. Madrid: Nacional.

Sandel, M. (2013). Lo que el dinero no puede comprar. Los límites morales del mercado. Barcelona: Debate.

Santos, B. (1998). La globalización del derecho. Bogotá: Universidad Nacional de Colombia, ILSA. 
Schnapper, B. (1973). Les Peines Arbitraires Du XIII ${ }^{\circ}$ au $\mathrm{XVIII}^{\circ}$ Siècle (Doctrines savants et usages francais). Tijdschrift voo Rechtsgeschiedenis=Revue d historie du droit, 237-277.

Sevilla de, I. (1951). Etimologías. Madrid: Católica.

Tomás y Valiente, F. (1969). El derecho penal de la monarquía absoluta (siglos XVI-XVII-XVIII). Madrid: Tecnos.

Wittgenstein, L. (1999). Investigaciones filosóficas. Barcelona: Altaya.

Zysman, D. (2012). Sociología del castigo. Genealogía de la determinación de la pena. Buenos Aires: Didot. 